\title{
Nociceptin/Orphanin-FQ Inhibits Gonadotropin- Releasing Hormone Neurons via G-Protein-Gated Inwardly Rectifying Potassium Channels
}

\author{
(1) Stephanie Constantin and 1 Susan Wray
}

https://doi.org/10.1523/ENEURO.0161-18.2018

Cellular and Developmental Neurobiology Section, National Institute of Neurological Disorders and Stroke/National Institutes of Health, Bethesda, Maryland 20892-3703

\begin{abstract}
The pulsatile release of gonadotropin-releasing hormone $(\mathrm{GnRH})$ is a key feature of the hypothalamic-pituitarygonadal axis. Kisspeptin neurons in the arcuate nucleus (ARC) trigger $\mathrm{GnRH}$ neuronal activity, but how $\mathrm{GnRH}$ neurons return to baseline electrical activity is unknown. Nociceptin/orphanin-FQ (OFQ) is an inhibitory neuromodulator. ARC proopiomelanocortin (POMC) neurons, known to receive inputs from ARC kisspeptin neurons, contact $\mathrm{GnRH}$ neurons and coexpress OFQ in the rat. In the present study, the effect of OFQ(1-13) on GnRH neurons was determined in the mouse. We identified transcripts for the OFQ receptor [opioid receptor like 1 (ORL1)] in GnRH neurons, and, using two-model systems (explants and slices), we found that OFQ exerted a potent inhibition on GnRH neurons, with or without excitatory inputs. We confirmed that the inhibition was mediated by ORL1 via $G_{i / o}$-protein coupling. The inhibition, occurring independently of levels of intracellular cyclic adenosine monophosphate, was sensitive to inwardly rectifying potassium channels. The only specific blocker of $\mathrm{G}_{\mathrm{i} / \mathrm{o}}$-protein-coupled inwardly rectifying potassium (GIRK) channels, tertiapin-Q (TPNQ), was ineffective in the inhibition of OFQ. Two GIRK activators, one sharing the binding site of TPNQ and one active only on GIRK1-containing GIRK channels, failed to trigger an inhibition. In contrast, protein kinase C phosphorylation activation, known to inhibit GIRK2-mediated currents, prevented the OFQ inhibition. These results indicate a specific combination of GIRK subunits, GIRK2/3 in GnRH neurons. In vivo, double-labeled OFQ/POMC fibers were found in the vicinity of GnRH neurons, and OFQ fibers apposed $\mathrm{GnRH}$ neurons. Together, this study brings to light a potent neuromodulator of $\mathrm{GnRH}$ neurons.
\end{abstract}

Key words: GIRK; GnRH; nociceptin; orphanin FQ; POMC

\section{Significance Statement}

Fertility is controlled centrally by neurons secreting gonadotropin-releasing hormone $(\mathrm{GnRH})$ and critically relies on their pulsatile secretory profile. GnRH pulses depend on kisspeptin neurons located in the arcuate nucleus. However, kisspeptin provides a long-lasting stimulation, and how $\mathrm{GnRH}$ neurons return to baseline electrical activity is unknown. Here, we show nociceptin/orphanin-FQ potently inhibits $\mathrm{GnRH}$ neurons. The signaling pathway involves the receptor, opioid receptor like 1, and downstream effectors $G_{i / 0}$-proteins and $\mathrm{G}_{\mathrm{i} / \mathrm{o}}$-protein-coupled inwardly rectifying potassium (GIRK) channels. Notably, the GIRK channels in $\mathrm{GnRH}$ neurons exhibit a specific subunit composition, GIRK2/3. Together, these data identify a new messenger in modulating reproductive function.

Received April 24, 2018; accepted December 3, 2018; First published December 12, 2018.

The authors declare no competing financial interests.
Author contributions: S.C. and S.W. designed research; S.C. and S.W. performed research; S.C. and S.W. analyzed data; S.C. and S.W. wrote the paper. 


\section{Introduction}

Fertility relies on the capacity of gonadotropin-releasing hormone $(\mathrm{GnRH})$ neurons to convert a wide range of cues from the CNS into a final hormonal signal to the pituitary, which subsequently controls the gonads. Steroids from the gonads feedback to the CNS providing the physiologic signals for coordinated communication along the $\mathrm{GnRH}-$ pituitary-gonadal axis and thus, reproductive success. Notably, $\mathrm{GnRH}$ is secreted in a pulsatile fashion (i.e., it must be initiated and stopped). Kisspeptin neurons are key players in the model for pulsatile release of $\mathrm{GnRH}$ (Mittelman-Smith et al., 2012; Navarro, 2012; Goodman et al., 2013). In this model, the action of stimulatory neurokinin $B$ and inhibitory dynorphin $A$ drives kisspeptin neurons into an oscillating firing mode that leads to pulsatile kisspeptin release. The phasic activity of $\mathrm{GnRH}$ neurons is subsequently triggered by kisspeptin. While dynorphin $A$ ends the kisspeptin release and therefore removes the excitation of $\mathrm{GnRH}$ neurons, exogenous kisspeptin triggers a long-lasting excitation in $\mathrm{GnRH}$ neurons, both at the cell body and at the terminal (Han et al., 2005; Constantin et al., 2009, 2013; Iremonger et al., 2017). The endogenous kisspeptin released after stimulation of the anteroventral periventricular nucleus (AVPV) also evokes the classical long-lasting effect (Liu et al., 2011). GnRH secretion seems to end while the kisspeptin induced excitation still persists (Glanowska and Moenter, 2015). To date, the identity of the molecule that terminates the bout of electrical activity and allows $\mathrm{GnRH}$ neurons to return to baseline electrical activity is unknown.

High levels of the nociceptin/orphanin FQ (OFQ) receptor ORL1 (opioid receptor like 1) are found in the preoptic area $(\mathrm{POA})$ and the anterior hypothalamic area where $\mathrm{GnRH}$ neurons reside (Houtani et al., 2000). In vitro, OFQ directly hyperpolarizes $\mathrm{GnRH}$ neurons in the arcuate nucleus (ARC; guinea pigs; Wagner et al., 1998), inhibits forskolin-evoked $\mathrm{GnRH}$ release from hypothalamic fragments (male rats; Dhandapani and Brann, 2002) and the spontaneous release of $\mathrm{GnRH}$ from mediobasal hypothalamus fragments [ovariectomized (OVX) rats; An et al., 2005]. In vivo, OFQ push-pull infusion inhibits $\mathrm{GnRH}$ release from the POA (OVX rats; An et al., 2005) and intracerebroventricular OFQ inhibits $\mathrm{GnRH}$ release from the median eminence (OVX rats; An et al., 2005, 2009). OFQ

This work was supported by the Intramural Research Program of the National Institutes of Health, National Institute of Neurological Disorders and Stroke (Grant ZIA-NS-002824-28).

We thank Shirley House and Katherine Pizano for help with immunohistochemistry; Aybike Saglam for help with confocal microscopy; Daniel Reynolds for help with calcium imaging; Drs. Juan Roa Rivas, Richard Piet, and Niteace Whittington for valuable comments on earlier drafts of this manuscript; and Dr. Oline Rønnekleiv for sharing the single-cell RT-PCR protocol.

Correspondence should be addressed to Dr. Susan Wray, Cellular and Developmental Neurobiology Section, National Institute of Neurological Disorders and Stroke, National Institutes of Health, 35 Convent Drive MSC 3703, Building 35, Room 3A1012, Bethesda, MD 20892. E-mail: wrays@ninds.nih.gov.

https://doi.org/10.1523/ENEURO.0161-18.2018

Copyright @ 2018 Constantin and Wray

This is an open-access article distributed under the terms of the Creative Commons Attribution 4.0 International license, which permits unrestricted use, distribution and reproduction in any medium provided that the original work is properly attributed. intracerebroventricular injections also decrease circulating luteinizing hormone (LH) levels (OVX rats; An et al., 2005) and blunts the preovulatory surge (OVX+estradiol/ progesterone rats; An et al., 2007). Pharmacology or RTPCR analysis support the effects being ORL1 dependent. Together, these data suggest that ORL1 is expressed on $\mathrm{GnRH}$ neurons, and OFQ may act as an inhibitory neuromodulator (Mollereau and Mouledous, 2000).

The ARC contains a variety of neuropeptides (Chronwall, 1985) including OFQ (Maolood and Meister, 2010; Campbell et al., 2017). Proopiomelanocortin (POMC) neurons are one of the ARC neuronal subpopulations that coexpress OFQ [male rats (Maolood and Meister, 2010); ewes (Nestor et al., 2013]. POMC neurons express both $\mathrm{ER} \alpha$ (Jirikowski et al., 1986; Xu et al., 2011) and progesterone receptor (Fox et al., 1990). ARC-specific (Yeo and Herbison, 2014) and POMC-specific (Xu et al., 2011) depletion of $\mathrm{ER} \alpha$ disrupted $\mathrm{LH}$ responses to estrogennegative feedback in female mice. Afferents from the ARC (Mezey et al., 1985; Wintermantel et al., 2006), and specifically from POMC neurons (Leranth et al., 1988; Simonian et al., 1999), are present in the vicinity of $\mathrm{GnRH}$ cell bodies in the preoptic area, and the response of $\mathrm{GnRH}$ neurons to the POMC-derived peptides, $\alpha$-melanocytestimulating hormone and $\beta$-endorphin, clearly supports a functional transsynaptic link between POMC neurons and GnRH neurons (Roa and Herbison, 2012). In contrast, the literature indicates that the POMC neurons in the nucleus of the solitary tract are unlikely to play a role in the control of fertility (Roa, 2013). In OVX ewes, the infusion of an ORL1 antagonist in the ARC does not affect LH pulses (Goodman et al., 2013) but, intracerebroventricular ORL1 antagonists increase LH levels under estradiol/progesterone supplementation, suggesting that OFQ may participate in progesterone-negative feedback (Nestor et al., 2013).

The present study shows Orl1 transcripts in $\mathrm{GnRH}$ cells and that $\mathrm{OFQ}$ inhibits $\mathrm{GnRH}$ neuronal activity, without GABAergic and glutamatergic inputs, and suppresses kisspeptin-10-evoked excitation. The signaling pathway, initiated by $O R L 1$, was identified as $\mathrm{G}_{\mathrm{i} / \mathrm{o}}$-type $\mathrm{G}$-protein coupling mediated by G-protein-coupled inwardly rectifying potassium (GIRK) channels, most likely GIRK2/3 heteromers. In addition, we found POMC fibers coexpressing OFQ in the vicinity of $\mathrm{GnRH}$ neurons and OFQ fibers contacting $\mathrm{GnRH}$ neurons in the POA, suggesting that these fibers might originate from $P O M C$ neurons in the ARC. Together, these data highlight N/OFQ as a potent in vivo inhibitory signal to $\mathrm{GnRH}$ neurons in the mouse.

\section{Materials and Methods}

\section{Animals}

All procedures were approved by National Institute of Neurologic Disorder and Stroke, Animal Care and Use Committee, and were performed in accordance with $\mathrm{Na}$ tional Institutes of Health (NIH) guidelines. Mice were maintained under $12 \mathrm{~h}$ light/dark lighting conditions, with food and water available ad libitum. Embryos were collected from timed-pregnant NIH Swiss mice at embryonic day 11.5, and nasal explants were generated (see below) 
Table 1: Primer sequences

\begin{tabular}{|c|c|c|c|}
\hline Gene (NCBI/GenBank ID) Reference Sequence) & Primers sequences ( $5^{\prime}$ to 3 ) & Annealing temperature & Product size \\
\hline GnRH-1 (NM_008145.2) & $\begin{array}{l}\text { CTG ATG GCC GGC ATT CTA CTG C } \\
\text { CCA GAG CTC CTC GCA GAT CCC }\end{array}$ & $66^{\circ} \mathrm{C}$ & $220 \mathrm{bp}$ \\
\hline Opioid receptor-like 1 (NM_011012.5) & $\begin{array}{l}\text { CAT GCC ATG CAG AAC CCA G } \\
\text { AGG GCT AGC TAC ATG CAC GA }\end{array}$ & $55^{\circ} \mathrm{C}$ & $209 \mathrm{bp}$ \\
\hline
\end{tabular}

for PCR and calcium imaging experiments. For in vivo immunocytochemistry, adult intact $\mathrm{GnRH}$-green fluorescent protein (GFP; Mouse Genome Informatics ID 6158458) male mice (Spergel et al., 1999) were used for $\mathrm{GnRH} / \mathrm{OFQ}$ and $\mathrm{GnRH} / \mathrm{POMC}$ staining, and adult intact C57BL/6 male mice were used for POMC/OFQ staining. Adult intact $\mathrm{GnRH}$-GFP male mice were also used to generate brain slices for electrophysiological experiments.

\section{GnRH cells maintained in nasal explants}

Explants were cultured as previously described (Fueshko and Wray, 1994). Briefly, gestational day 11.5 embryos (undetermined sex) were obtained from timemated pregnant NIH Swiss mice. Nasal pits were dissected under aseptic conditions in Gey's Balanced Salt Solution (Life Technologies) supplemented with glucose (Sigma-Aldrich). Explants were adhered onto coverslips by a plasma (Cocalico Biologicals)/thrombin (SigmaAldrich) clot and maintained in a defined serum-free medium (SFM) in a humidified atmosphere at $37^{\circ} \mathrm{C}$ with $5 \%$ $\mathrm{CO}_{2}$. On culture day 3, SFM was replaced by fresh SFM containing fluorodeoxyuridine (2.3 $\mu \mathrm{M}$; Sigma-Aldrich) for $3 \mathrm{~d}$ to inhibit the proliferation of dividing olfactory neurons and non-neuronal explant tissue. On culture day 6 , and every $2 \mathrm{~d}$ afterward, the medium was changed with fresh SFM.

\section{PCR on CDNA from single GNRH neurons maintained in explants}

Poly(A)-amplified cDNA libraries were generated from single $\mathrm{GnRH}$ neurons using two different techniques (Kramer, 2002; Bosch et al., 2013). Every single-cell cDNA pool generated was first tested by PCR for GnRH (Giacobini et al., 2004). Cellular material without reverse transcriptase, and no cellular material (water), served as negative controls. Specific primers were designed in the 3 -untranslated region of the genes encoding ORL1 within $300 \mathrm{bp}$ before the polyadenylation site. All designed primers were screened using NCBI BLAST (Basic Local Alignment Search Tool; Johnson et al., 2008) to ensure specificity. For each reaction, $1 \times$ PCR buffer, $2 \mathrm{~mm}$ $\mathrm{MgCl}$, $250 \mu \mathrm{M}$ each deoxynucleotide mix (Life Technologies), 125-250 nм forward primer, 125-250 nм reverse primer, and 2.5 U AmpliTaq Gold (Life Technologies) were added to 1-3 $\mu$ l template cDNA. PCR was performed as follows: initial 10 min denaturation $\left(94^{\circ} \mathrm{C}\right) ; 40-50$ cycles with denaturation $30 \mathrm{~s}\left(94^{\circ} \mathrm{C}\right)$; annealing for $30 \mathrm{~s}(55-$ $66^{\circ} \mathrm{C}$ ) and extension for $2 \mathrm{~min}\left(72^{\circ} \mathrm{C}\right)$; followed by $10 \mathrm{~min}$ postelongation at $72^{\circ} \mathrm{C}$. Amplified products were run on a $1.5 \%$ agarose gel. Specific bands of the predicted size were observed in control total brain, whereas no bands were seen in water. The sequences of the primers are listed in Table 1.

\section{Calcium imaging}

GnRH neurons exhibit calcium oscillations that correlate with bursts of action potentials (APs; Constantin and Wray, 2008); therefore, calcium imaging was used as a reflection of $\mathrm{GnRH}$ neuronal activity. Experiments were performed as previously described (Constantin et al., 2009). Explants were used between 6 and $11 d$ in culture (Fig. 1A). Briefly, Calcium Green-1 AM (Life Technologies) was dissolved at $2.7 \mathrm{~mm}$ in dimethylsulfoxide containing $20 \%$ pluronic F-127 (Life Technologies), then diluted down to $13.5 \mu \mathrm{M}$ in SFM (loading solution), aliquoted, and kept frozen until use. Explants were incubated in warm loading solution for $20 \mathrm{~min}$ at $37^{\circ} \mathrm{C}$ in a $5 \% \mathrm{CO}_{2}$ humidified incubator. After washes in fresh SFM, explants were mounted in a perfusion chamber (Warner Instruments) and continuously perfused at a rate of $\sim 300 \mu \mathrm{l} / \mathrm{min}$. Calcium imaging experiments were performed at $25^{\circ} \mathrm{C}$. Calcium Green-1 was visualized using an inverted microscope (Eclipse TE2000-E, Nikon), through a 20× fluorescence objective [Fluor 20×; numerical aperture (NA), 0.75; working distance (WD), $1.0 \mathrm{~mm}$ ] and a charge-coupled device camera (QImaging) connected to a computer. Time-lapse recording was piloted by iVision imaging software (Scanalytics), and pictures were acquired every $2 \mathrm{~s}$. Excitation wavelengths were provided with a mediumwidth excitation bandpass filter at $465-495 \mathrm{~nm}$, and emission was monitored through a $40 \mathrm{~nm}$ bandpass centered on $535 \mathrm{~nm}$. Calcium imaging recordings were divided into periods. The treatment period was preceded by a control period in SFM, followed by a washout period. When possible, drugs were sequentially added through multiple treatment periods. When a drug required a long pretreatment [i.e., pertussis toxin (PTX) or tertiapin-Q (TPNQ)], recordings were started during the last $10 \mathrm{~min}$ of pretreatment to determine the basal level of $\mathrm{GnRH}$ neuronal activity. All recordings were terminated with a $40 \mathrm{mM} \mathrm{KCl}$ stimulation to ensure the viability of the cells. The changes in fluorescence over time were measured in single, phase bright, bipolar cells with iVision and analyzed with MATLAB (MathWorks) as previously described (Constantin and Wray, 2008). The phenotype of these bipolar cells, defined as regions of interest, was confirmed using chromogen immunocytochemistry against $\mathrm{GnRH}$. Due to the heterogeneity of $\mathrm{GnRH}$ neuronal population, a large number of cells were sampled for each paradigm. The individual cells $(n)$ originating from at least three explants $(N)$ independently recorded were combined for each paradigm. Explants $(N=65)$ contained on average $29.5 \pm 2.0$ identified $\mathrm{GnRH}$ neurons in a recording field. 
A

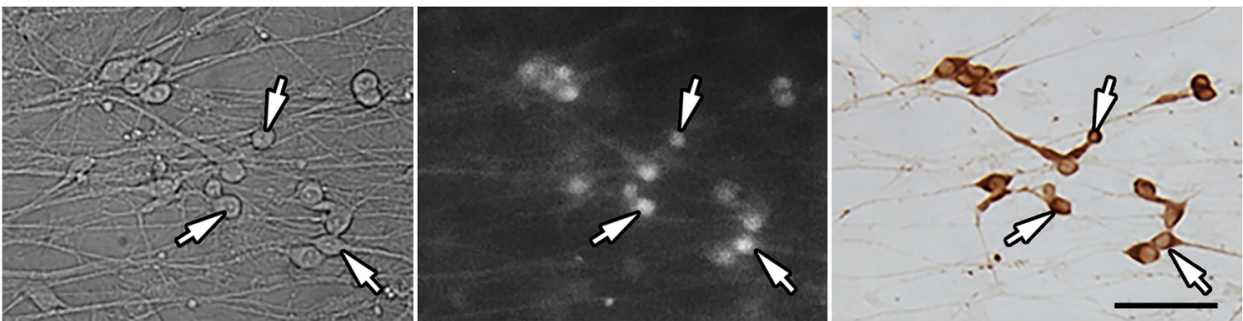

B

single GnRH neurons

controls
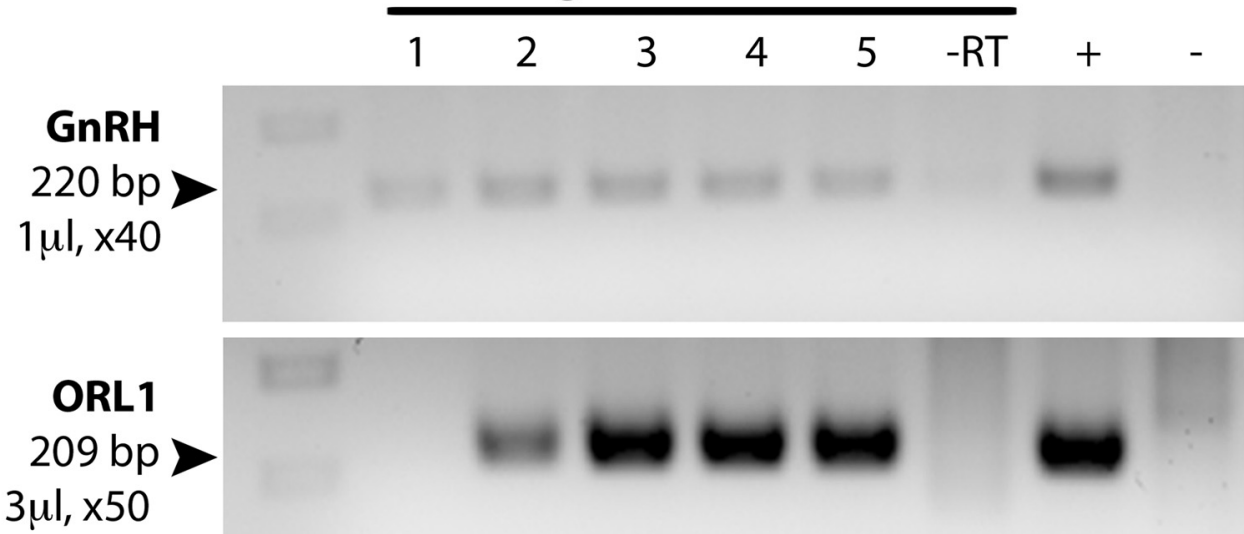

Figure $1 \mathrm{GnRH}$ neurons express the N/OFQ receptor ORL1. $\boldsymbol{A}$, High-magnification image of GnRH neurons (arrows) recorded with calcium imaging. Initially identified by their bipolar morphology (left), GnRH neurons loaded with the calcium-sensitive dye Calcium Green-1 AM (middle) were imaged. The phenotype of cells was confirmed post hoc by immunocytochemistry (right). Scale bar, $50 \mu \mathrm{m}$. $\boldsymbol{B}$, Embryonic $\mathrm{GnRH}$ neurons express Orl1. Transcripts for the receptor ORL1 were found in single GnRH neurons. Adult brain was used as positive control and water and reverse transcriptase were used as negative controls, respectively. The volume of template and number of cycles are as indicated.

\section{Immunocytochemistry for GnRH}

After calcium imaging, explants $(6-11 \mathrm{~d})$ were fixed for 30 min with $0.1 \mathrm{M}$ PBS, pH 7.4, containing $4 \%$ formaldehyde at room temperature. After a few washes in PBS, explants were incubated in a blocking solution $(10 \%$ normal horse serum plus $0.3 \%$ Triton $\mathrm{X}-100)$ for $1 \mathrm{~h}$, and washed several times in PBS. The explants were incubated at $4^{\circ} \mathrm{C}$ overnight in the primary antibody $(\mathrm{rbGnRH}$; Wray et al., 1989b; Table 4). The next day, explants were washed in PBS, incubated for $1 \mathrm{~h}$ with biotinylated secondary donkey anti-rabbit antibody (1:500 in PBS/0.3\% Triton X-100; Vector Laboratories), washed in PBS, and processed for avidin-biotin horseradish peroxidase/3,3'diaminobenzidine (Fig. 1A).

\section{Immunofluorescent labeling}

Three explants $(6-11$ d) were fixed, washed, and blocked as described above. The explants were then incubated $\left(4^{\circ} \mathrm{C}\right.$ overnight) in the GIRK2 primary antibody, which has been shown to give no signal in GIRK2 knockout mice (Marron Fernandez de Velasco et al., 2017). The next day, explants were washed in PBS, and the first primary antibody was visualized using Alexa Fluor 488conjugated secondary donkey anti-rabbit antibody $(1 \mathrm{~h}$, $1: 1000$ in PBS/0.3\% Triton X-100). Explants were then washed, fixed for $10 \mathrm{~min}$, washed, and incubated in the second primary antibody [mouse $\mathrm{GnRH}(\mathrm{mGnRH}) ; 2 \mathrm{~d}]$.
After washing (PBS), the second primary antibody was visualized using Alexa Fluor 555-conjugated secondary donkey anti-mouse antibody (1:1000 in PBS/0.3\% Triton X-100). After several washes in PBS and water, explants were coverslipped with an anti-fade mounting solution. Controls $(N=$ 3 ) in which the anti-GIRK2 primary antibody was omitted resulted in only background staining.

Adult mice, anesthetized with isoflurane then killed with an intraperitoneal overdose of ketamine $(20 \mathrm{mg} / 20 \mathrm{~g})$, were transcardially perfused with $0.1 \mathrm{~m}$ PBS then $4 \%$ formaldehyde in PBS. The brains were removed and postfixed in the same fixative $(1 \mathrm{~h})$, then transferred to a $30 \%$ sucrose-PBS solution overnight. The next day, the brains were frozen in dry ice and kept at $-80^{\circ} \mathrm{C}$ until sectioning. Four sets of coronal sections $(40 \mu \mathrm{m})$ were cut with a sliding microtome and kept at $-20^{\circ} \mathrm{C}$ in cryoprotectant (Hoffman et al., 2008) until staining. After washes in PBS, sections were incubated for $1.5 \mathrm{~h}$ in a blocking solution (see above), washed several times in PBS, and incubated in primary antibodies. Three different adult males were used for each staining.

\section{OFQ or POMC staining and GFP staining in GnRH- GFP mice}

Sections were incubated at $4^{\circ} \mathrm{C}$ (2 nights) in the first primary antibody (OFQ or POMC). The next day, sections were washed in PBS, incubated for $1.5 \mathrm{~h}$ with Alexa Fluor 555-conjugated secondary donkey anti-rabbit antibody 
Table 2: Frequencies of calcium oscillations in GnRH neurons

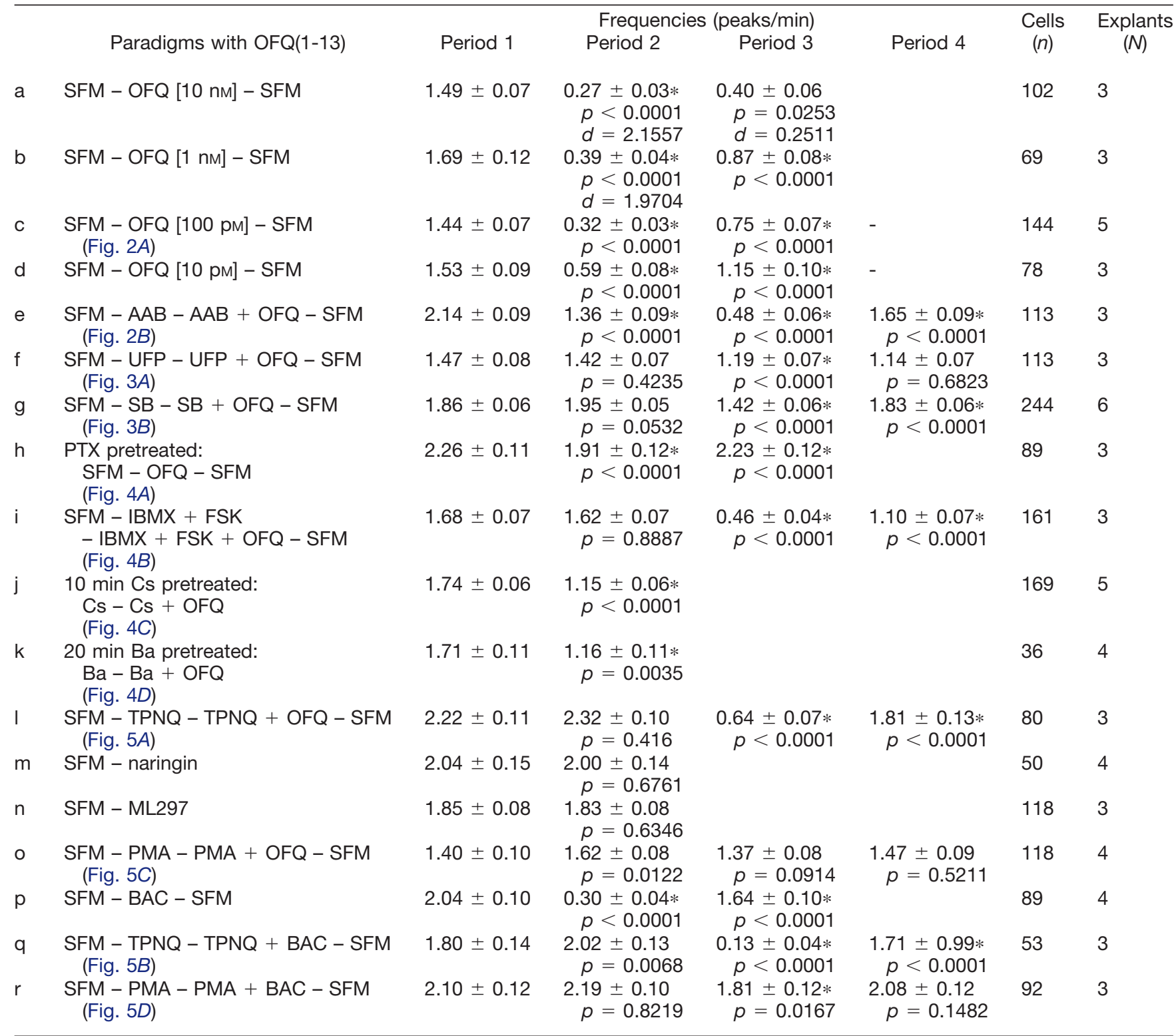

Concentrations used: OFQ, 100 pm (unless stated); AABs (BIC, $20 \mu \mathrm{m}$; CNQX, $10 \mu \mathrm{m}$; D-AP5, $10 \mu \mathrm{M})$; UFP, 10 nм; SB, 10 nм; PTX, 250 ng/ml; IBMX, $10 \mu \mathrm{m}$; FSK, $1 \mu \mathrm{m}$; Cs, $5 \mathrm{~mm} ; \mathrm{Ba}, 400 \mu \mathrm{M}$; TPNQ, $500 \mathrm{nM}$; naringin, $500 \mu \mathrm{M}$; ML297, $10 \mu \mathrm{M}$; BAC, $10 \mu \mathrm{M}$; PMA, $50 \mathrm{~nm}$. Data are expressed as the mean \pm SEM.

*Significant difference compared with the previous period (period 2 with period 1 or period 3 with period 2 or period 4 with period 3 ) using repeated-measures one-way ANOVA, followed by Sidak's multiple-comparisons test $(p<0.01)$. For rows $\mathrm{j}$, $\mathrm{k}$, $\mathrm{m}$, and $\mathrm{n}$, a paired Student's $t$ test was used to compare period 2 with period $1(p<0.01)$.

(1:1000 in PBS/0.3\% Triton X-100). After several washes in PBS, sections were rapidly fixed with PBS containing $4 \%$ formaldehyde, washed, and incubated at $4^{\circ} \mathrm{C}$ (for 2 nights) in the second primary antibody (GFP). The next day, sections were washed in PBS and incubated for 1.5 h with Alexa Fluor 488-secondary donkey anti-chicken antibody (1:1000 in PBS/0.3\% Triton X-100). After several washes in PBS and water, sections were coverslipped with an anti-fade mounting solution.

\section{OFQ and POMC staining}

To avoid cross-reactivity between two primary antibodies raised in a rabbit, staining was performed as described previously (Shindler and Roth, 1996; Hoffman et al., 2008). Sections were incubated at $4^{\circ} \mathrm{C}$ (for 2 nights) in the first primary antibody (POMC; Elkabes et al., 1989). The next day, sections were washed in PBS, incubated with biotinylated secondary donkey anti-rabbit antibody $(1 \mathrm{~h}$, 1:1000 in PBS/0.3\% Triton X-100). After washes in PBS, sections were incubated in avidin-biotin complex $(1 \mathrm{~h}$, $1: 500$ in PBS/0.3\% Triton X-100), washed in PBS, and incubated in tyramide (20 min, 1:200 in PBS/0.3\% Triton $\mathrm{X}-100 / 0.005 \% \mathrm{H}_{2} \mathrm{O}_{2}$; PerkinElmer). Then sections were washed, incubated with streptavidin Texas Red (1.5 h,1: 200 in PBS/0.3\% Triton X-100; PerkinElmer), washed, fixed (10 min), washed, and incubated (2 d) in the second 

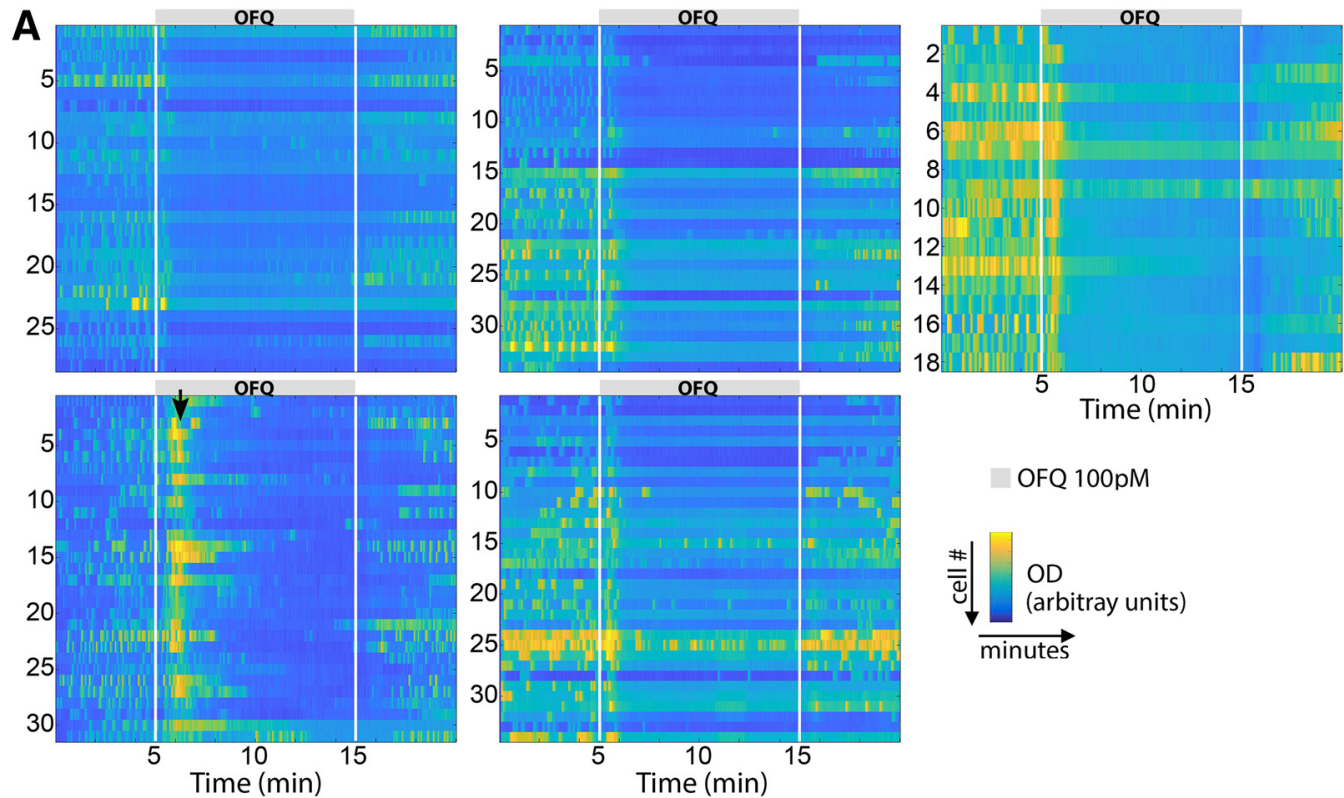

OFQ 100pM

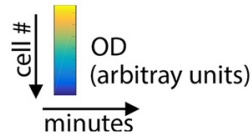

B
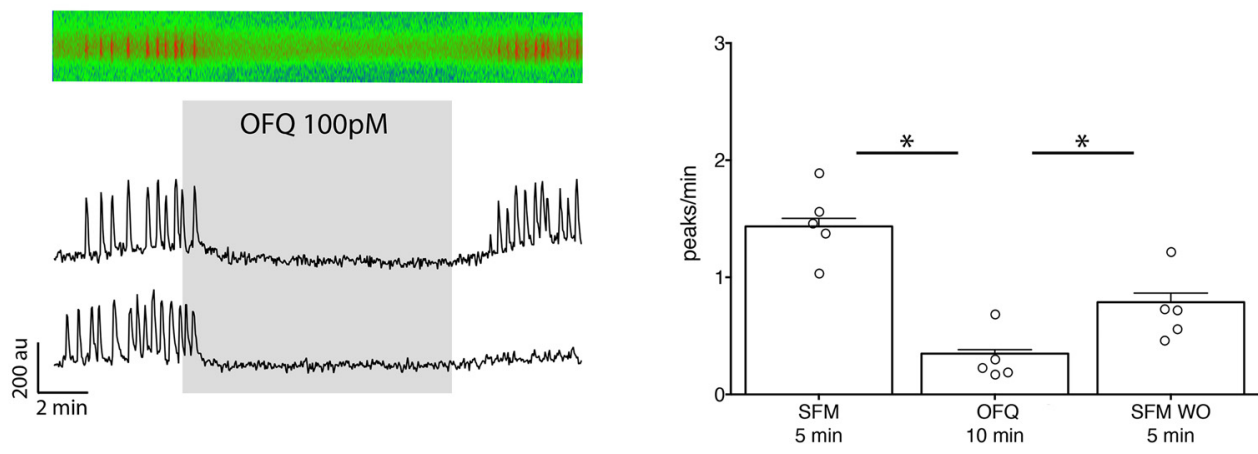

C
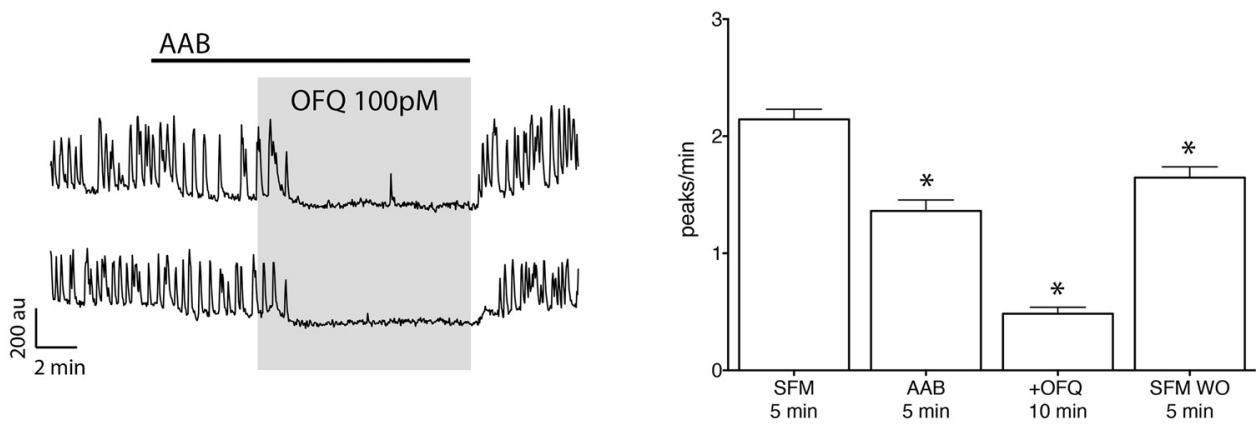

Figure 2. OFQ inhibits GnRH neuron calcium oscillation, independent of GABAergic and glutamatergic inputs. $\boldsymbol{A}$, Heatmaps of changes in levels of intracellular calcium in cells recorded simultaneously during the paradigm in $\boldsymbol{B}$, independently repeated in five different explants. Each row represents changes in a single cell. White lines indicate the time of drug application. Note the consistency of the response to OFQ within each explant and across explants (Fig. 2-1). B, Left, Calcium-imaging recordings of explants showing OFQ (100 pm) evoked a potent decrease in the frequency of calcium oscillations in GnRH neurons (kymograph from the cell shown on the top trace). Right, Empty circles, Summary data showing the average frequency of calcium oscillations for each explant. To minimize the impact of the cell-to-cell heterogeneity, the values from all individual cells originating from the five explants in $\boldsymbol{A}$ were combined. Bars, Summary data showing the average frequency of calcium oscillations in all $\mathrm{GnRH}$ neurons tested during the control (SFM), treatment (OFQ), and the washout (SFM WO) periods $(n=144, N=5)$. au, Arbitrary unit. $*$ Statistical significance between two consecutive periods. $\boldsymbol{C}$, Left, The OFQ-evoked inhibition persisted in the presence of AABs (BIC, $20 \mu \mathrm{M}$; CNQX, $10 \mu \mathrm{M}$; D-AP5, $20 \mu \mathrm{M})$. Right, Summary data showing the average frequency of calcium oscillations in all GnRH neurons tested during the control (SFM), pretreatment (AAB), treatment (+OFQ), and washout (SFM WO) periods $(n=113, N=3)$. 
A

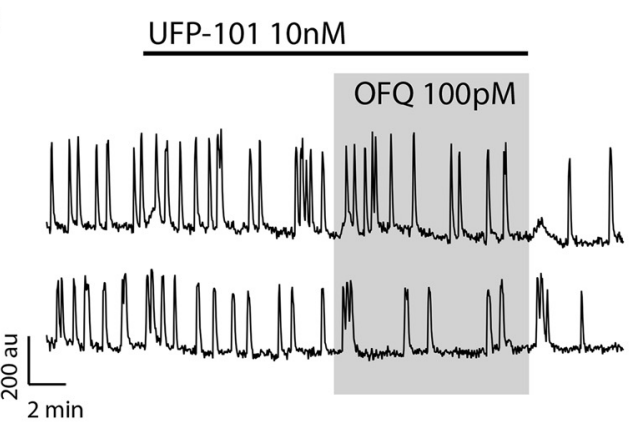

B

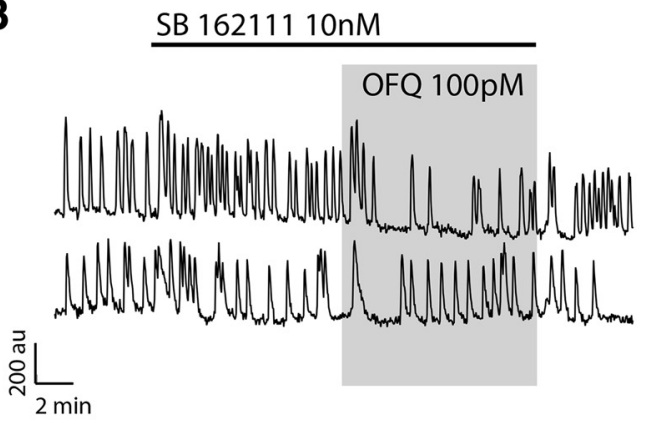

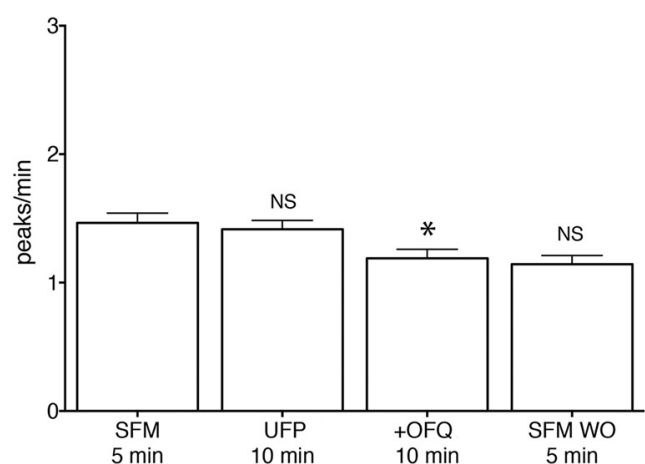

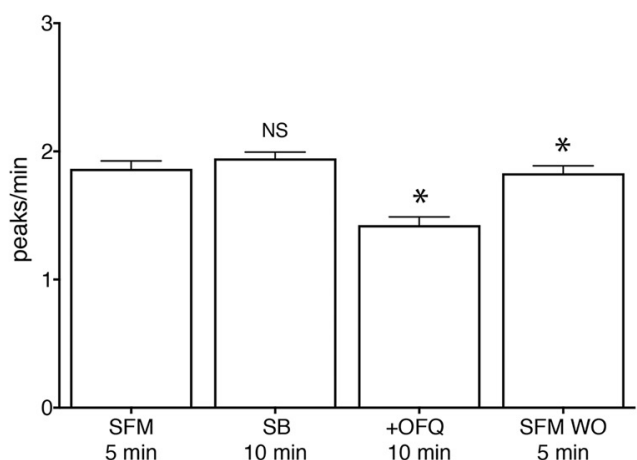

Figure 3. OFQ-evoked inhibition of GnRH neuronal activity is mediated by the receptor ORL1. $\boldsymbol{A}$, Left, Calcium imaging recordings showing OFQ-evoked largely reduced inhibition in the presence of the ORL1 antagonist UFP-101. Right, Summary data showing the average frequency of calcium oscillations in all GnRH neurons tested during the control (SFM), pretreatment (UFP-101), treatment (+OFQ), and the washout (SFM WO) periods $(n=113, N=3)$. au, Arbitrary unit. $*$ Statistical significance between two consecutive periods. $\boldsymbol{B}$, Left, The ORL1 antagonist SB also reduced the OFQ-evoked inhibition. Right, Summary data showing the average frequency of calcium oscillations in all GnRH neurons tested during the control (SFM), pretreatment (SB 162111), treatment (+OFQ), and washout (SFM WO) periods $(n=244, N=6)$.

primary antibody (OFQ). Sections were then washed in PBS, incubated with Alexa Fluor 488-conjugated donkey anti-rabbit antibody $(1.5 \mathrm{~h}, 1: 1000$ in PBS/0.3\% Triton $\mathrm{X}-100$ ), washed in PBS, and mounted and coverslipped with an anti-fade mounting solution. For triple labeling (one series/animal), an antigen retrieval method was used before initiating the immunocytochemistry (Jiao et al., 1999), and staining for $\mathrm{GnRH}$ was performed after staining for POMC and OFQ using an GnRH antibody raised in chicken. Sections were incubated for $2 \mathrm{~d}$, washed, and visualized with Alexa Fluor 647-conjugated donkey antichicken antibody.

Table 3: Inhibition of GnRH neurons

\begin{tabular}{|c|c|c|c|c|}
\hline & Paradigms with OFQ(1-13) & $\begin{array}{l}\text { Period (with OFQ) - Period (without OFQ)/ } \\
\text { Period (with OFQ) (change in \%) }\end{array}$ & $\begin{array}{l}\text { Cells } \\
(n)\end{array}$ & $\begin{array}{l}\text { Explants } \\
(N)\end{array}$ \\
\hline a & SFM - OFQ & $-75.6 \pm 2.0$ & 144 & 5 \\
\hline $\mathrm{b}$ & UFP - UFP + OFQ & $-17.3 \pm 3.3 *(p<0.0001)$ & 112 & 3 \\
\hline c & $\mathrm{SB}-\mathrm{SB}+\mathrm{OFQ}$ & $-29.5 \pm 2.5 *(p<0.0001)$ & 244 & 6 \\
\hline$d$ & $\begin{array}{l}\text { PTX pretreated: } \\
\text { SFM - OFQ }\end{array}$ & $-17.4 \pm 4.4 *(p<0.0001)$ & 88 & 3 \\
\hline e & $\mathrm{IBMX}+\mathrm{FSK}-\mathrm{IBMX}+\mathrm{FSK}+\mathrm{OFQ}$ & $-68.2 \pm 2.6(p>0.9864)$ & 161 & 3 \\
\hline$f$ & $\mathrm{Cs}-\mathrm{Cs}+\mathrm{OFQ}$ & $-28.6 \pm 3.6 *(p<0.0001)$ & 168 & 5 \\
\hline g & $\mathrm{Ba}-\mathrm{Ba}+\mathrm{OFQ}$ & $-12.0 \pm 4.9 *(p<0.0001)$ & 36 & 4 \\
\hline $\mathrm{h}$ & $T P N Q-T P N Q+O F Q$ & $-72.9 \pm 2.5(p>0.9999)$ & 80 & 3 \\
\hline i & 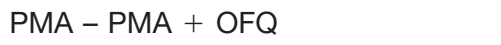 & $18.7 \pm 16.8 *(p<0.0001)$ & 113 & 4 \\
\hline j & SFM - BAC & $-86.2 \pm 1.9$ & 88 & 4 \\
\hline $\mathrm{k}$ & $T P N Q-T P N Q+B A C$ & $-93.5 \pm 1.5(p=0.9206)$ & 53 & 3 \\
\hline 1 & $P M A-P M A+B A C$ & $19.9 \pm 20.5 *(p<0.0001)$ & 92 & 3 \\
\hline
\end{tabular}

Concentrations used: OFQ, 100 рм; UFP, 10 nм; SB, 10 nм; PTX, 250 ng/ml; IBMX, $10 \mu \mathrm{m} ;$ FSK, $1 \mu \mathrm{m} ;$ Cs, 5 mм; Ba, $400 \mu \mathrm{m} ;$ TPNQ, 500 nм; PMA, 50 nм; BAC, $10 \mu \mathrm{M}$. Data are expressed as the mean \pm SEM.

*Significant difference $(p<0.01$ ), using one-way ANOVA, followed by Dunnett's multiple-comparisons test using OFQ (row a) as a reference for rows b-i or BAC (row j) as a reference for rows $k$ and $\mathrm{l}$ ). 


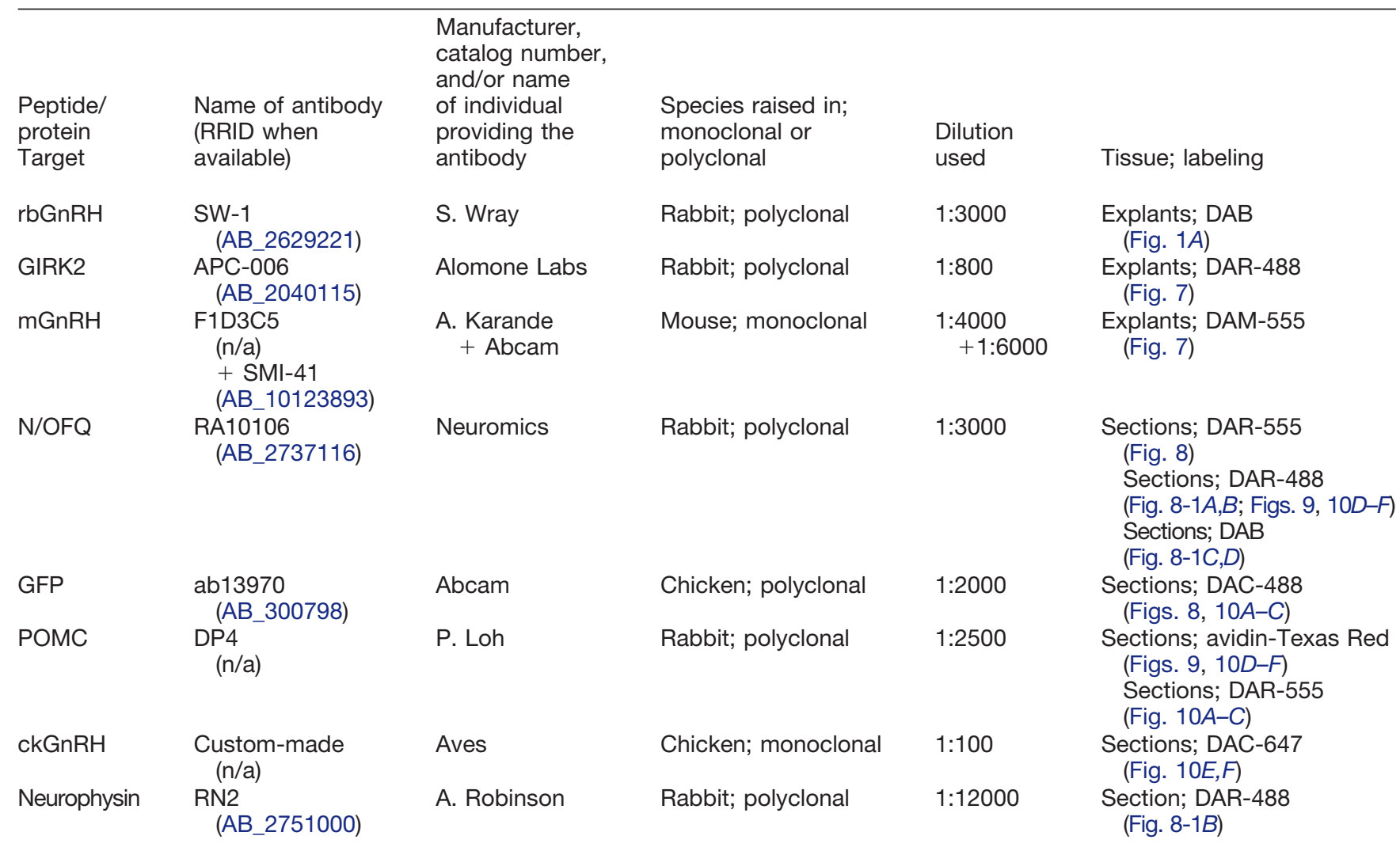

DAB, 3,3'-diaminobenzidine; DAM, donkey anti-mouse; DAR, donkey anti-rabbit; DAC, donkey anti-chicken.

All immunofluorescent pictures were taken using spinning disk confocal (Yokogawa) microscopy (Eclipse TE200, Nikon) though a $60 \times$ water-immersion objective (Nikon Plan Apo 60×; NA, 1.2; WD, $0.27 \mathrm{~mm}$ ), captured with a high-sensitivity camera (EM-CCD, Hamamatsu Photonics) and presented as a flattened confocal stack or a single focal plan.

The specificity of the OFQ antibody was confirmed by the presence of a signal on previous documented structures, as follows: (1) suprachiasmatic nucleus, (2) trigeminal ganglion, and (3) dorsal root ganglion (Fig. 8-1).

\section{Electrophysiology}

Male mice were chosen to avoid the possible influence of fluctuating circulating steroids. GnRH-GFP mice were killed at $\sim 1030 \mathrm{~h}$ by cervical dislocation then decapitated. The brain was removed from the skull, glued to the vibratome plate, submerged with iced-cold low [Ca]/high [Mg] (0.5 and $6 \mathrm{~mm}$, respectively) artificial CSF (aCSF), and bubbled with $95 \% \mathrm{O}_{2} / 5 \% \mathrm{CO}_{2}$. Conventional coronal sections $(200 \mu \mathrm{m})$ were cut using a vibratome (VT1000S, Leica). After sectioning, slices were incubated at $30^{\circ} \mathrm{C}$ in normal aCSF containing, as follows: $118 \mathrm{~mm} \mathrm{NaCl}, 3 \mathrm{~mm}$ $\mathrm{KCl}, 2.5 \mathrm{~mm} \mathrm{CaCl} 2,1.2 \mathrm{~mm} \mathrm{MgCl} 2,10 \mathrm{~mm}$ HEPES, $25 \mathrm{~mm}$ $\mathrm{NaHCO} 3$, and $11 \mathrm{~mm}$ D-glucose, $\mathrm{pH}$ 7.3, bubbled with $95 \% \mathrm{O}_{2} / 5 \% \mathrm{CO}_{2}$. Individual slices were transferred into a recording chamber mounted on an upright microscope (Eclipse FN1, Nikon) and continuously superfused with oxygenated normal aCSF maintained at $28-30^{\circ} \mathrm{C}$ at a rate of $\sim 2 \mathrm{ml} / \mathrm{min}$ (Constantin et al., 2012). Individual GnRH neurons were identified with fluorescence $(20 \mathrm{~nm}$ narrow bandpass EGFP filter centered at $480 \mathrm{~nm}$ ) using a $40 \times$ water-immersion objective $(40 \times / 0.80 \mathrm{~W}$; WD, $2.0 \mathrm{~mm}$; Nikon). Visualized with a charge-coupled device camera (Retiga EXi Blue, QImaging) and piloted by the open source software Micro-Manager version 1.4, the neurons were patched under fluorescence and differential interference contrast. The pipettes (3-5 M 2 ) were backfilled with aCSF. Electrophysiological recordings were acquired with a Multiclamp 700B amplifier (Molecular Devices) using a low-pass filter at $10 \mathrm{kHz}$ and digitized by a Digidata (1550) analog-to-digital converter at $10 \mathrm{kHz}$ (Molecular Devices).

\section{Drugs}

Cesium ( $\mathrm{Ca})$, barium [Ba; both broad-spectrum blockers of inwardly rectifying potassium $\left(\mathrm{K}_{\mathrm{ir}}\right)$ channels], naringin (GIRK channel activator), phorbol 12-myristate 13acetate [PMA; protein kinase $C$ (PKC) activator], and baclofen (BAC; $\mathrm{GABA}_{\mathrm{B}}$ receptor agonist) were purchased from Sigma-Aldrich. 3-isobutyl-1-methylxanthine (IBMX; inhibitor of phosphodiesterase), forskolin (FSK; activator of adenylyl cyclase), 6-Cyano-7-nitroquinoxaline-2,3dione (CNQX; AMPA/kainate receptor antagonist), D(-)2-amino-5-phosphonopentanoic acid (D-AP5; NMDA receptor antagonist), bicuculline $\left(\mathrm{BIC} ; \mathrm{GABA}_{\mathrm{A}}\right.$ receptor antagonist), TPNQ (blocker of GIRK channels), UFP-101 (UFP) and SB 162111 (SB; two selective antagonists for ORL1 receptor), PTX (uncoupling $\mathrm{G}_{\mathrm{i} / \mathrm{o}}$-protein-coupled re- 
A

PTX-pretreated

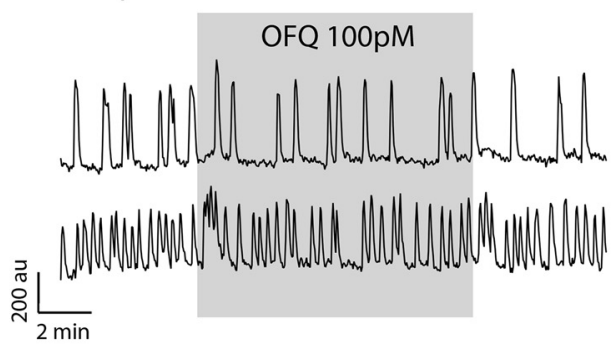

B

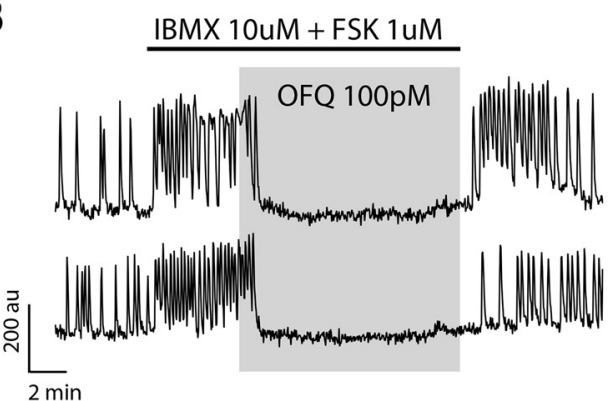

\section{C $\quad$ ss $5 \mathrm{mM}$}

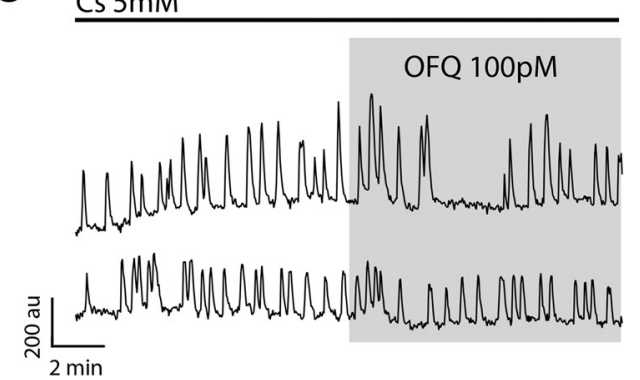

D

Ba $400 u M$

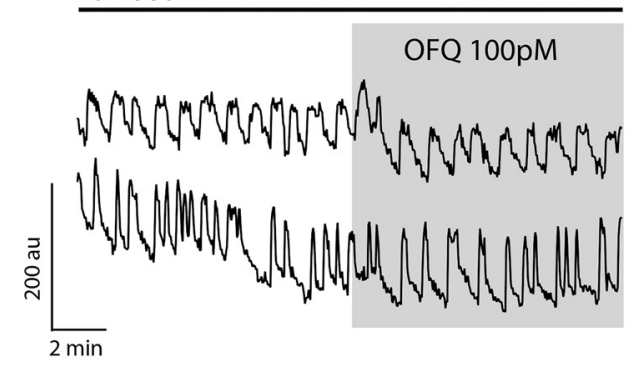

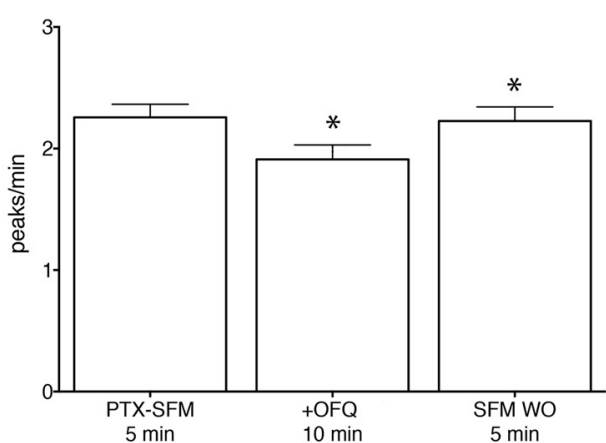
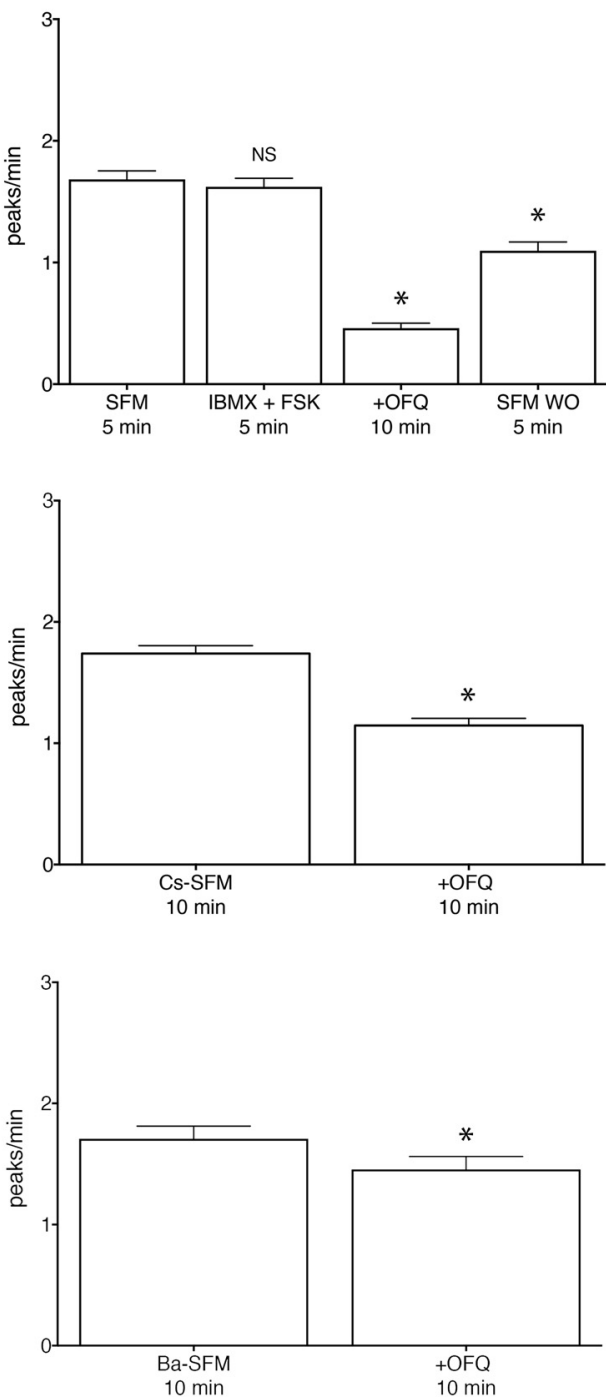

Figure 4. The receptor $O R L 1$ is $G_{i / o}$ coupled and activates GIRK channels to inhibit GnRH neuronal activity. $\boldsymbol{A}$, Left, Calcium imaging recordings, after a $4 \mathrm{~h}$ pretreatment with PTX $(250 \mathrm{ng} / \mathrm{ml})$, showing OFQ (100 PM) evoked only a mild inhibition of GnRH neuronal activity. Right, Summary data showing the average frequency of calcium oscillations in all GnRH neurons pretreated with PTX and tested during the control (PTX-SFM), treatment (+OFQ), and washout (SFM WO) periods $(n=89, N=3)$. au, Arbitrary unit. *Statistical significance between two consecutive periods. $\boldsymbol{B}$, Left, The OFQ-evoked inhibition is insensitive of IBMX and FSK. Right, Summary data showing the average frequency of calcium oscillations in all GnRH neurons tested during control (SFM), pretreatment (IBMX + FSK), treatment (+OFQ), and washout (SFM WO) periods $(n=161, N=3)$. Note that the IBMX + FSK treatment is not showing a significant increase due to the calcium plateau evoked in some cells, which results in an underestimate of peak detection. $\boldsymbol{C}, \boldsymbol{D}$, Left, The broad-spectrum blocker of $\mathrm{K}_{\mathrm{ir}}$ channels, $\mathrm{Cs}$ or Ba, reduced the OFQ-evoked inhibition. Right, Summary data showing the average frequency of calcium oscillations in all $\mathrm{GnRH}$ neurons pretreated with $\mathrm{Cs}$ or $\mathrm{Ba}$ and tested during the pretreatment $(\mathrm{Cs}$ or $\mathrm{Ba})$ and treatment (+OFQ) periods (Cs: $n=169, N=5$; Ba: $n=36, N=4)$. 
A

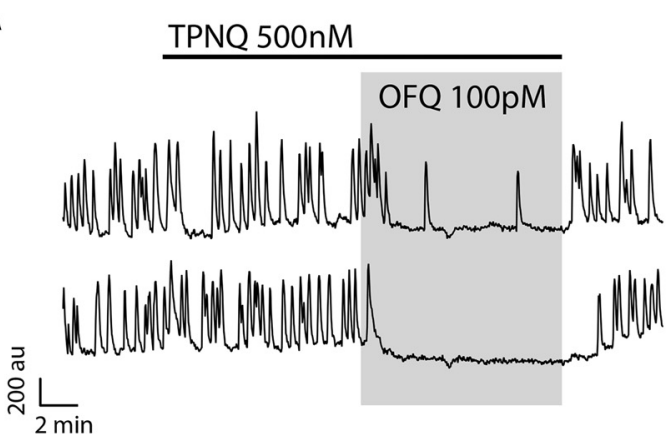

B

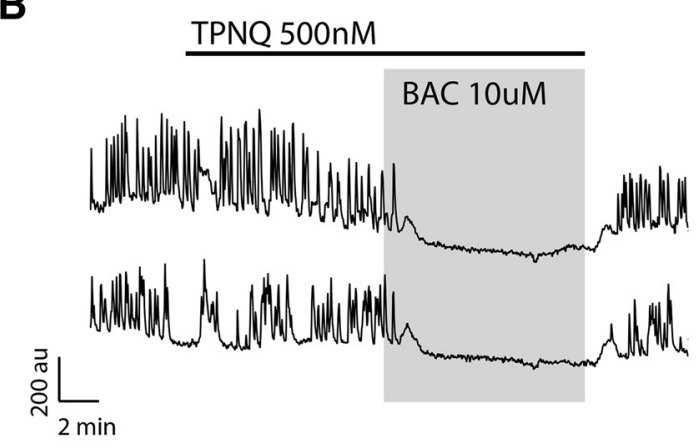

C

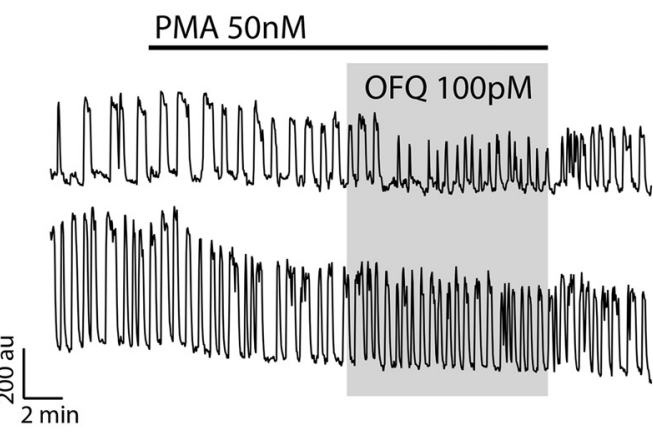

D

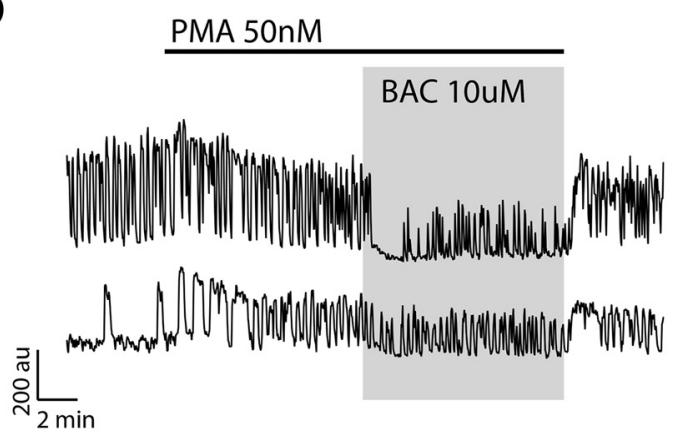

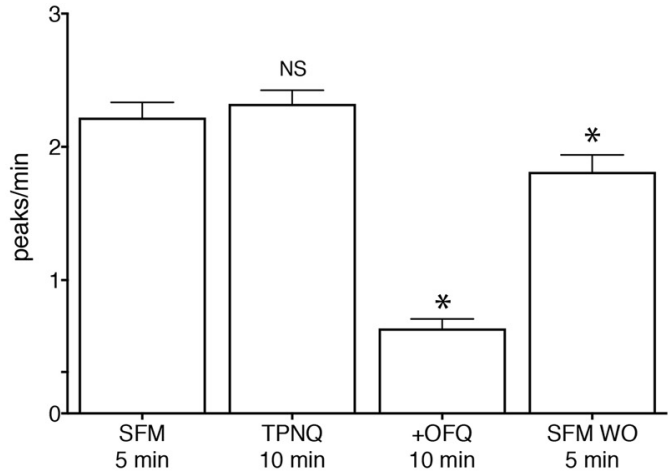
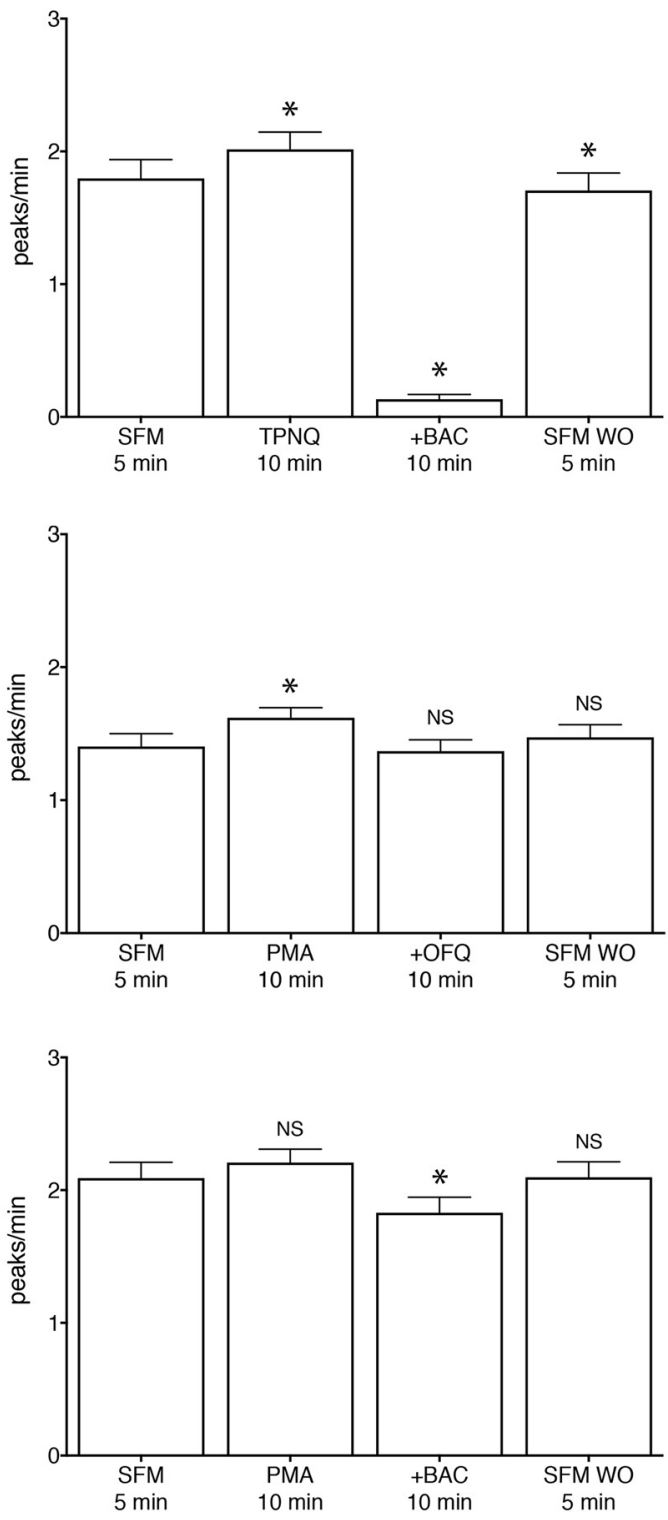

Figure 5. The OFQ-evoked inhibition activates GIRK channels, insensitive to tertiapin-Q but inhibited by protein kinase $\mathrm{C}$ phosphorylation. $\boldsymbol{A}$, Left, Calcium imaging recordings showing that a specific blocker of G-protein inwardly rectifying potassium channels, TPNQ, was ineffective on the OFQ-evoked inhibition. Right, Summary data showing the average frequency of calcium oscillations in all GnRH neurons tested during control (SFM), pretreatment (TPNQ), treatment (+OFQ), and washout (SFM WO) periods $(n=80$, $N=3$ ). au, arbitrary unit. $*$ Statistical significance between two consecutive periods. $\boldsymbol{B}$, Left, TPNQ was also ineffective on $\mathrm{GABA}_{\mathrm{B}}$-evoked inhibition with BAC. Right, Summary data showing the average frequency of calcium oscillations in all GnRH neurons tested during control (SFM), pretreatment (TPNQ), treatment (+BAC), and washout (SFM WO) periods $(n=20, N=2)$. $\boldsymbol{C}$, Left, The 
continued

protein kinase C activator PMA prevented OFQ-evoked inhibition. Right, Summary data showing the average frequency of calcium oscillations in all GnRH neurons tested during control (SFM), pretreatment (PMA), treatment (+OFQ), and washout (SFM WO) periods $(n=118, N=4)$. $\boldsymbol{D}$, Left, PMA was also profoundly blunted the $\mathrm{GABA}_{\mathrm{B}}$-evoked inhibition. Right, Summary data showing the average frequency of calcium oscillations in all $\mathrm{GnRH}$ neurons tested during control (SFM), pretreatment (PMA), treatment (+BAC), and washout (SFM WO) periods $(n=92, N=3)$.

ceptor), ML297 (GIRK channel activator) and human kisspeptin-10 [kp-10; Tyr-Asn-Trp-Asn-Ser-Phe-Gly-LeuArg-Phe-NH2] were purchased from Tocris Bioscience. Nociceptin/orphanin FQ (1-13)-NH2 [OFQ; Phe-Gly-GlyPhe-Thr-Gly-Ala-Arg-Lys-Ser-Ala-Arg-Lys-NH2] was purchased from Phoenix. All stock solutions $(1000 \times$ or $500 \times)$ were stored at $-20^{\circ} \mathrm{C}$ and diluted prior to each experiment at the specified concentration in SFM.

Note that throughout the calcium-imaging and electrophysiology result sections, OFQ refers to the truncated form, OFQ(1-13)-NH2, exogenously applied.

\section{Statistical analysis}

For calcium imaging, comparisons of the frequencies of calcium oscillations (in peaks/min) were performed using a repeated measurement one-way ANOVA with Greenhouse-Geisser correction, and post hoc Sidak's multiplecomparisons test between two consecutive recording periods for paradigms (Table 2). A paired Student's $t$ test was used for two-period paradigms (Table 2). The strength of inhibition was determined for each cell and was expressed as the percentage of the pre-OFQ period as follows: [(peaks/min before OFQ) - (peaks/min during OFQ)]/(peaks/min before OFQ) $\times 100$. Comparisons of the strength of inhibition between groups of cells were performed with one-way ANOVA, and post hoc Dunnett's multiple-comparisons test, using OFQ as the reference. In the Results section and figures, the frequencies of calcium oscillations are expressed as the mean \pm SEM, and $n$ and $N$ represent the number of cells and explants recorded, respectively.

For electrophysiology, the OFQ-induced inhibition was determined as follows: APs were detected with Clampfit 10 on continuous recordings, and the firing frequency (in $\mathrm{Hz}$ ) was determined by summing APs into $1 \mathrm{~s}$ bins. The average firing frequency was calculated over the last minute of each recording period, control before OFQ, during OFQ and washout after OFQ ( $<6 \mathrm{~min})$. When firing was not regained spontaneously, kisspeptin-10 was applied to validate the period of silence. Periodograms (in $\mathrm{Hz}$ ) were performed by summing APs into $10 \mathrm{~s}$ bins. A Student's paired $t$ test was performed between two consecutive recording periods. $n$ and $N$ represent the number of cells and the number of animals the cells are recorded from, respectively. In calcium imaging, significant differences were defined by a $p$ value $<0.01$ due to the large number of cells that can be sampled; in electrophysiology, significant differences were defined by a $p$ value $<0.05$.

\section{Results}

RT-PCR analysis revealed the presence of transcripts coding for the ORL1 gene ( $n=14$ and 19) in single $\mathrm{GnRH}$ neurons maintained in nasal explants using two different single-cell RT-PCRs ( $n=15$ and 19; Fig. 1B).

\section{Orphanin FQ (1-13) directly inhibits GnRH neurons maintained in explants}

OFQ was applied to 6-11 d explants at four different concentrations (10 nм, $1 \mathrm{~nm}, 100 \mathrm{pm}$, and $10 \mathrm{pm}$ ). All doses inhibited $\mathrm{GnRH}$ neuronal activity (Table 2, rows a-d, Fig. 2). The mean response of individual explants was quantified to assess whether the OFQ response might be sex specific. OFQ evoked a potent inhibition of $\mathrm{GnRH}$ neurons in every explant tested ( $N=20$, from all four doses combined; Fig. 2-1); therefore, the sex of the embryo from which the explant was generated is highly unlikely to define the responsiveness to OFQ. At $100 \mathrm{pm}, \sim 90 \%$ of the cells showed $a \geq 50 \%$ inhibition with OFQ, and the inhibition was not correlated with cell location within the explant periphery (Fig. 2A). The dose of 100 pм was chosen for all subsequent experiments, as it was the smallest dose with robust effects (Fig. 2B).

In explants, the spontaneously occurring $\mathrm{GnRH}$ neuronal activity is mainly regulated by GABAergic and glutamatergic inputs (Constantin et al., 2010). GABA $_{B}$ receptors are not endogenously activated in this model at 6-11 d in vitro (Constantin et al., 2010), and metabotropic glutamatergic receptors are unlikely to play a major role on $\mathrm{GnRH}$ neurons (Chu and Moenter, 2005; Dumalska et al., 2008). Thus, the application of OFQ was repeated in the presence of an amino acid blocker (AAB) cocktail (BIC, $20 \mu \mathrm{M}$; CNQX, $10 \mu \mathrm{M}$; D-AP5, $10 \mu \mathrm{M}$ ) to inhibit $\mathrm{GABA}_{\mathrm{A}}$ receptors and ionotropic glutamatergic inputs. The OFQ inhibition persisted in the presence of $A A B$ (Table 2, row e), demonstrating a direct effect of OFQ on $\mathrm{GnRH}$ neurons (Fig. 2C). Approximately $75 \%$ of the cells showed $a \geq 50 \%$ inhibition with $A A B$ plus OFQ.

\section{The receptor of orphanin FQ, ORL1, mediates the OFQ inhibition}

UFP is a selective antagonist for ORL1 receptors (Calo et al., 2002). Pretreatment of GnRH neurons with UFP (10 nM) did not completely prevent OFQ-induced inhibition (Table 2, row f, Fig. 3A) but dramatically attenuated it (Table 3 , rows a and b), with only $\sim 12 \%$ of the cells showing $a \geq 50 \%$ inhibition. The effectiveness of UFP-101 is shown with cells losing their ability to respond to the second dose of OFQ (see Fig. 6A,B). The experiment was repeated with $S B$, another selective antagonist for ORL1 receptors. Pretreatment of $\mathrm{GnRH}$ neurons with $\mathrm{SB}$ (10 nM) also attenuated OFQ inhibition (Tables 2, row g, 3, rows a and c, Fig. $3 B$ ) with $\sim 35 \%$ of the cells showing $a \geq 50 \%$ inhibition. These data support the binding of OFQ to ORL1 receptors in $\mathrm{GnRH}$ neurons. Note that UFP and SB did not have any effect on their own (Table 2, rows $f$ and $g$ ). 
A

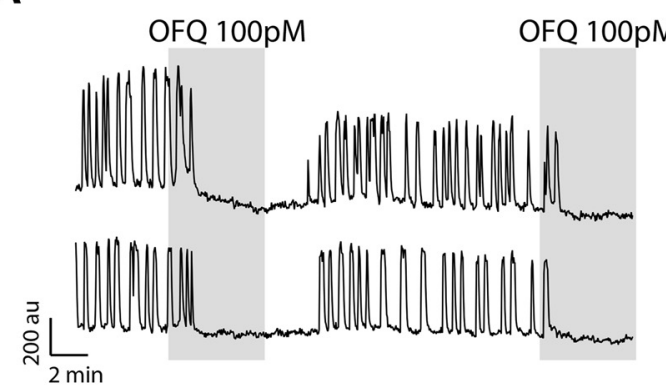

B
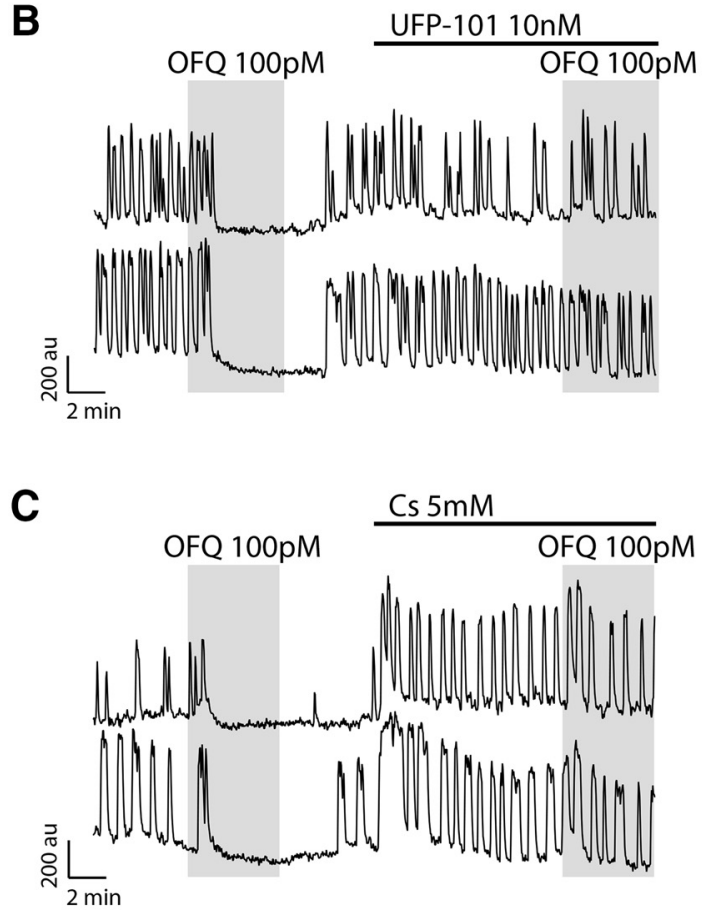

D

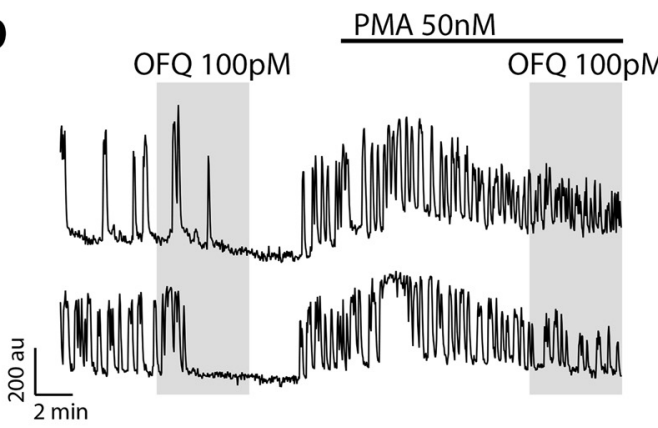

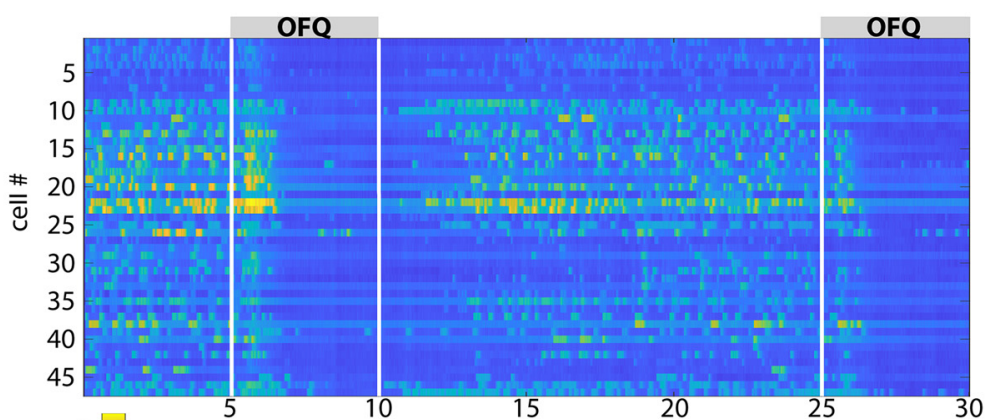

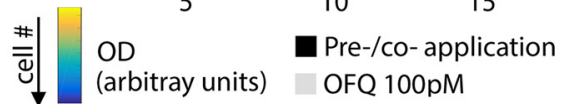
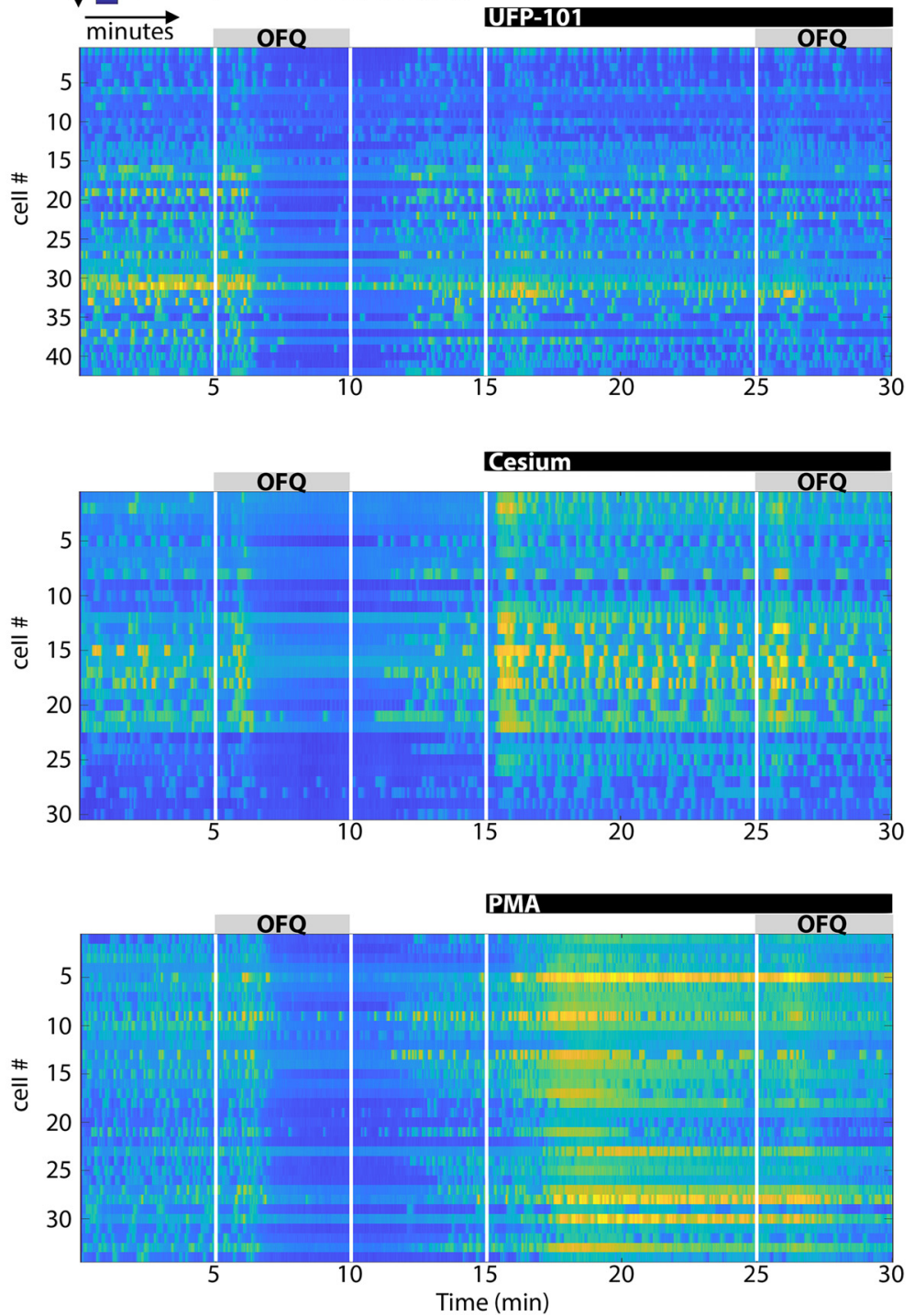

Figure 6. Blockers are effective in GnRH neurons identified as OFQ responsive. $\boldsymbol{A}-\boldsymbol{D}$, Left, Calcium imaging recordings of explants showing that OFQ (100 pm) evoked a potent decrease in the frequency of calcium oscillations in GnRH neurons (first application, $\boldsymbol{A}-\boldsymbol{D}$ ). The inhibition is repeatable (second application, $\boldsymbol{A}$ ) and blocked by UFP-101 (ORL1 antagonist), cesium (broad-spectrum blocker of $\mathrm{K}_{\text {ir }}$ channels), and PMA (PKC activator). $\boldsymbol{A}-\boldsymbol{D}$, Right, Heatmaps of changes in the levels of intracellular calcium in cells recorded simultaneously during different paradigms (left). Each row represents changes in a single cell. White lines indicate the time of drug application. Note the large number of GnRH cells inhibited by OFQ (first application, $\boldsymbol{A}-\boldsymbol{D}$ ), the repeatability of the inhibition (second application, $\boldsymbol{A}$ ), and the effectiveness of UFP-101 (ORL1 antagonist), cesium (broad-spectrum blocker of $\mathrm{K}_{\mathrm{ir}}$ channels), and PMA (PKC activator; $\boldsymbol{B}, \boldsymbol{C}$, and $\boldsymbol{D}$, respectively, second application) to prevent OFQ inhibition. Note the homogeneity of the response throughout the cells within an explant. 

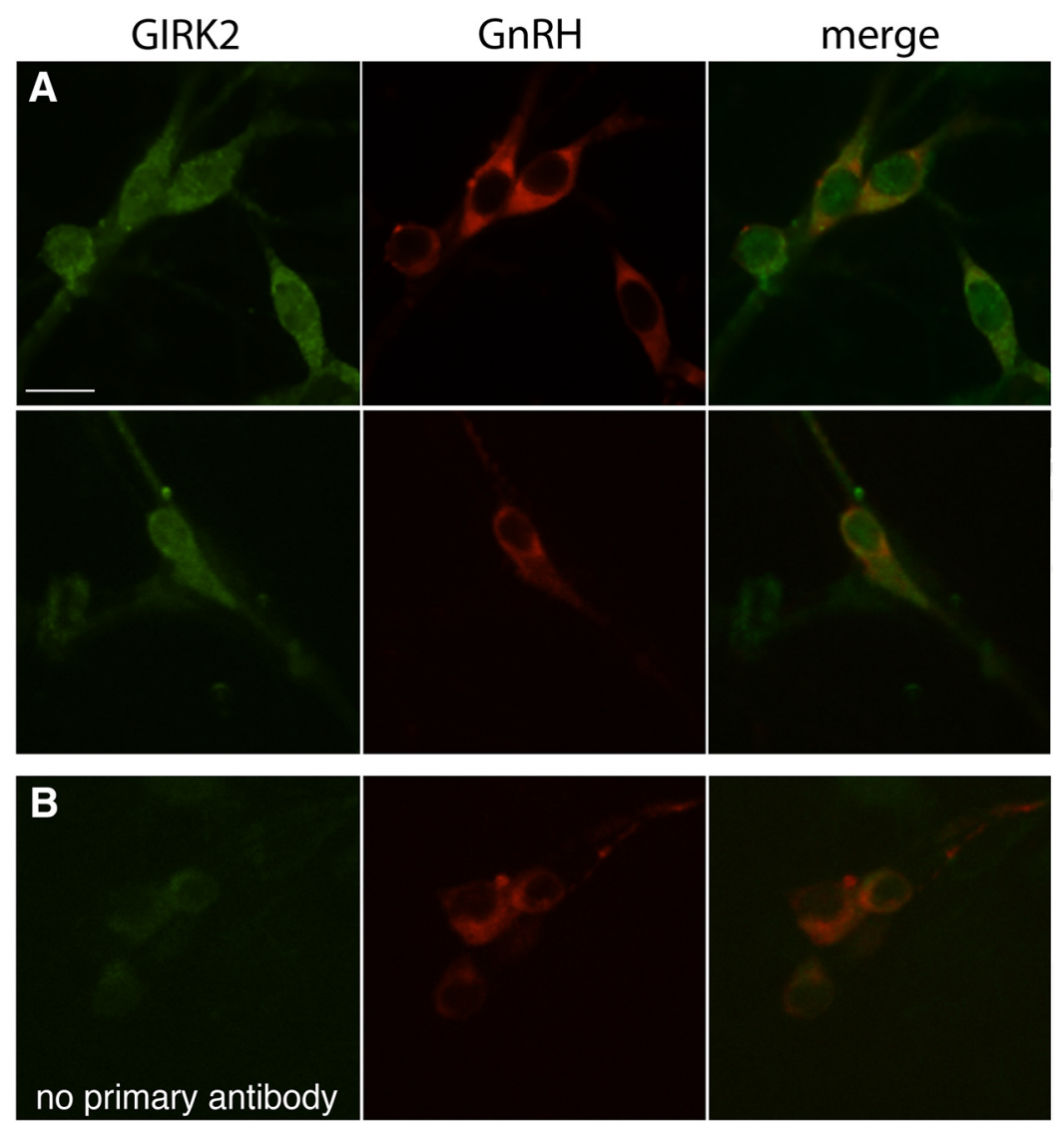

Figure 7. GnRH neurons are immunoreactive for GIRK2 (K 3.2$)$. A, Single confocal plans showing GnRH neurons (red), colabeled with GIRK2 (green; scale bar, $10 \mu \mathrm{m})$ in 11-d-old explants $(N=3)$. Representative pictures showing all GnRH neurons examined were colabeled with the GIRK2 antibody. B, Single confocal plans showing GnRH neurons (red), with background (green) when GIRK2 antibody was omitted and used to set the camera at the level of nonspecific staining; the experiment was run simultaneously with the one shown in the second row in $\boldsymbol{A}$.

\section{OFQ inhibition in GnRH cells is mediated by $\mathrm{G}_{\mathrm{i} / \mathrm{o}}$-protein-coupled inwardly rectifying potassium channels}

It has been reported that ORL1 receptors couple to a $\mathrm{G}_{\mathrm{i} / \mathrm{o}}$-type G-protein (Ikeda et al., 1997). Thus, explants were treated with PTX $(250 \mathrm{ng} / \mathrm{ml})$ for $>4 \mathrm{~h}$ to uncouple $\mathrm{G}_{\mathrm{i} / \mathrm{o}}$-proteins from its receptors. PTX treatment attenuated OFQ inhibition of $\mathrm{GnRH}$ neurons (Tables 2, row h, 3, rows a and d, Fig. 4A). A canonical pathway downstream of a $\mathrm{G}_{\mathrm{i} / \mathrm{o}}$-type protein is a decrease in the activity of adenylyl cyclase and cyclic adenosine monophosphate. However, coapplication of IBMX $(10 \mu \mathrm{M})$ and FSK $(1 \mu \mathrm{M})$, inhibiting phosphodiesterase and activating adenylyl cyclase, respectively, had no effect on OFQ inhibition of GnRH neurons (Tables 2, row i, 3, rows a and e, Fig. 4B). Alternatively, $\mathrm{G}_{\mathrm{i} / \mathrm{o}}$-proteins can be coupled to GIRK channels, also known as $\mathrm{K}_{\mathrm{ir}} 3$, voltage-independent potassium channels (Klenke et al., 2010; Constantin and Wray, 2016). The application of OFQ was repeated in the presence of Cs $(5 \mathrm{mM})$ or $\mathrm{Ba}(400 \mu \mathrm{M})$, broad-spectrum blockers of $\mathrm{K}_{\mathrm{ir}}$ channels, added 10 and $20 \mathrm{~min}$, respectively, before OFQ. Although $\mathrm{Cs}$ or Ba did not fully block the OFQ inhibition (Table 2, rows j and k, Fig. 4C,D; also see Fig. $6 C$ ), both strongly reduced its magnitude (Table 3 , rows $a$ and $f$ or $g$ ), supporting the coupling of ORL1 receptors to GIRKs, as previously shown (Wagner et al., 1998).

Unlike the broad-spectrum $\mathrm{K}_{\mathrm{ir}}$ blockers cesium and barium, TPNQ is known as a GIRK-specific channel blocker. Unexpectedly, TPNQ (500 nm; Wu et al., 2011), added $10 \mathrm{~min}$ before OFQ, did not prevent the OFQ inhibition (Table 2, row I, Fig. 5A) and had no effect on its magnitude (Table 3 , rows $a$ and $h$ ). It is widely agreed that $\mathrm{GABA}_{\mathrm{B}}$ receptors are mediated by GIRK channels (Kahanovitch et al., 2017), including in $\mathrm{GnRH}$ neurons (Zhang et al., 2009). Thus, the effect of TPNQ was tested on the inhibition triggered by the activation of $G A B A_{B}$ receptor. As with OFQ, TPNQ had no effect on BAC inhibition (Table 2, rows $p$ and q, Fig. 5B) or its magnitude (Table 3 , rows $j$ and $k$ ), and confirmed the ineffectiveness of TPNQ on GnRH GIRK channels. Naringin (500 $\mu \mathrm{M})$, which is an activator of GIRK channels using the same binding site as TPNQ (Yow et al., 2011), also did not change $\mathrm{GnRH}$ neuronal activity (Table 2, row $\mathrm{m}$ ).

GIRK channels are tetramers and can form with three neuronal subtypes, GIRK1 $\left(\mathrm{K}_{\mathrm{ir}} 3.1\right)$, GIRK2 $\left(\mathrm{K}_{\mathrm{ir}} 3.2\right)$, and GIRK3 (K $\left.\mathrm{K}_{\mathrm{ir}} 3.3\right)$. GIRK2 can form a homotetramer, while GIRK1 and GIRK3 require heteromerization for functionality. Previous RT-PCR analysis had found transcripts for Kcnj3 (GIRK1) in GnRH neurons (Constantin and Wray, 

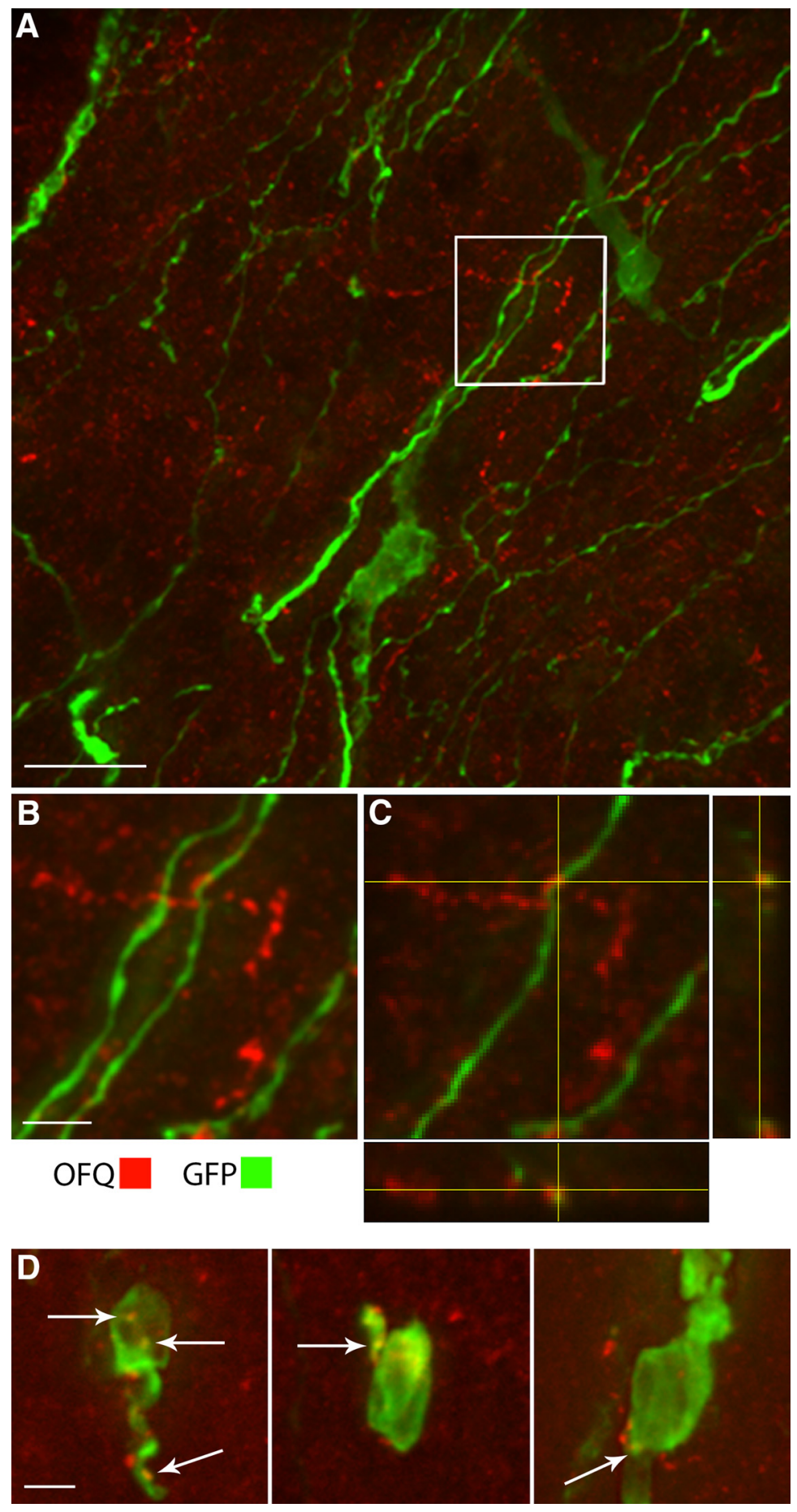

Figure 8. POA GnRH neurons are apposed by OFQ-immunoreactive fibers. A, Representative stack of confocal images showing $\mathrm{GnRH}$ neurons labeled with GFP- (green) and OFQ- (red) immunoreactive fibers in the POA of an adult male mouse. Scale bar, $20 \mu \mathrm{m}$. Enlarged image from boxed area in $\boldsymbol{B}$. Scale bar, $5 \mu \mathrm{m}$. $\boldsymbol{C}$, Single confocal plan from the boxed area showing an OFQimmunoreactive fiber apposed to a $\mathrm{GnRH}$ fiber. $\boldsymbol{D}$, Representative stacks of confocal images showing $\mathrm{GnRH}$ neuron cell bodies contacted by an OFQ-immunoreactive fiber (arrows, merged yellow). Scale bar, $5 \mu \mathrm{m}$. The specificity of the OFQ antibody is shown in Figure 8-1.

2016). However, ML297 (10 $\mu \mathrm{M})$, an activator of GIRK1containing tetramers (Kaufmann et al., 2013) had no effect on $\mathrm{GnRH}$ neuronal activity (Table 2, row n). RT-PCR data also identified transcripts for Kcnj9 (GIRK3) in GnRH neurons (Klenke et al., 2010). Since GIRK2 and GIRK3 are less sensitive or insensitive to TPNQ, respectively (Nockemann et al., 2013; Whorton and MacKinnon, 2013; Llamosas et al., 2017), an alternative approach was used to clarify the role of GIRK channels in the OFQ inhibition. GIRK channels are inhibited through a PKC-dependent 


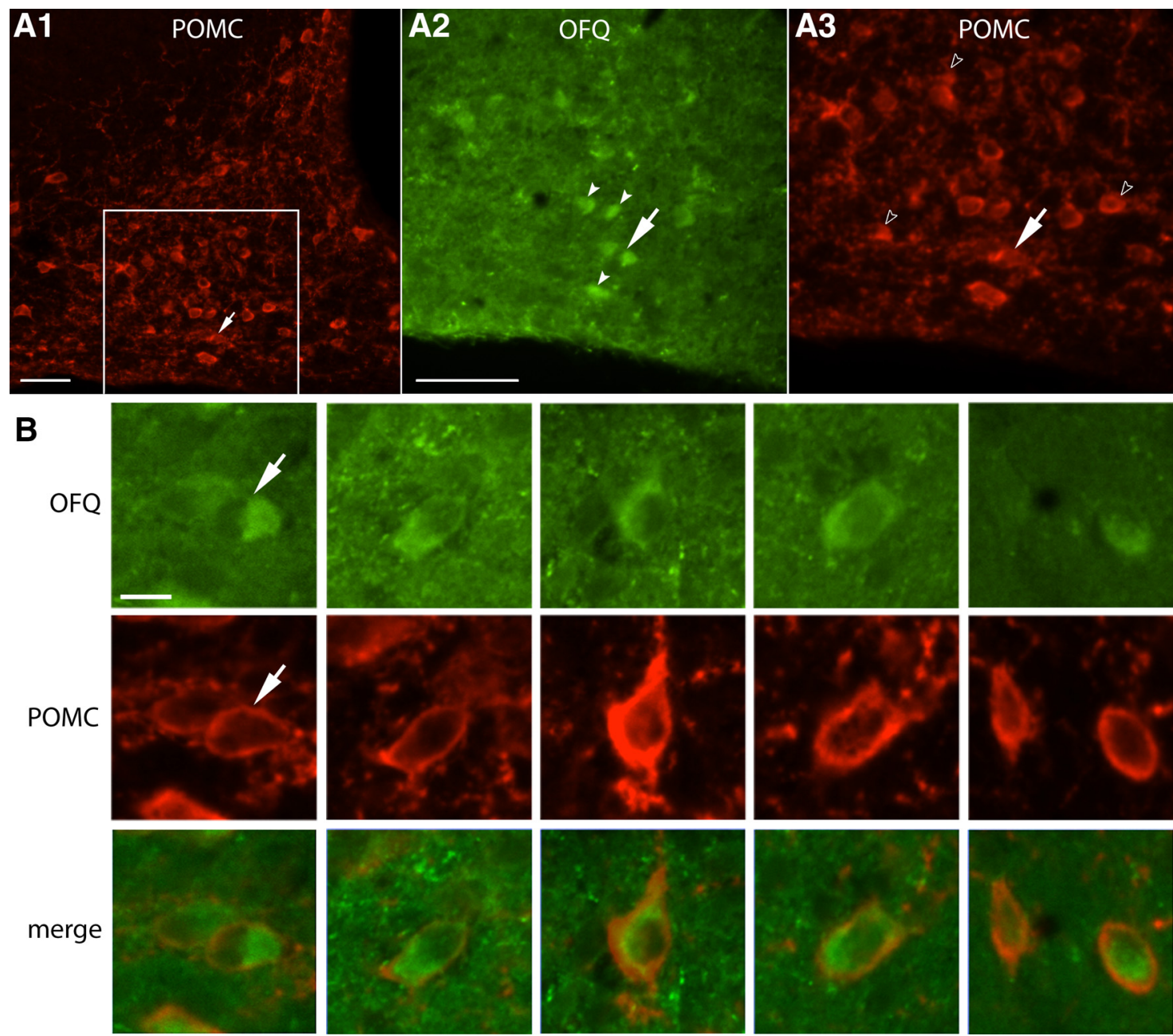

Figure 9. A subset of $A R C P O M C$ neurons is colabeled with OFQ. A1-A3, Representative photographs showing ARC neurons immunoreactivity for POMC (red) and OFQ (green) in an adult male mouse. The box in $\boldsymbol{A} 1$ is enlarged in $\boldsymbol{A} 2$ and $\boldsymbol{A} 3$ to show a lateral subset of POMC neurons colabeled with OFQ (low magnification, $\boldsymbol{A 1}$; high magnification, $\boldsymbol{A 2}, \boldsymbol{A}$ ). Scale bars, $50 \mu \mathrm{m}$. The arrows in $\boldsymbol{A} \mathbf{2}$ and $\boldsymbol{A} 3$ point to the neuron indicated in the high-magnification images in $\boldsymbol{B}$. White arrowheads in $\boldsymbol{A} 2$ show OFQ neurons colabeled with POMC in $\boldsymbol{A 3}$. Empty arrowheads in $\boldsymbol{A}$ 3 show POMC neurons that are not colabeled with OFQ in $\boldsymbol{A 2}$. $\boldsymbol{B}$, Representative photographs showing examples of ARC POMC neurons coexpressing OFQ. Scale bar, $10 \mu \mathrm{m}$.

mechanism (Stevens et al., 1999). The PKC activator PMA (50 nM) was applied before OFQ, and OFQ failed to inhibit GnRH neurons (Table 2, row o, Fig. 5C; Table 3, rows a and i, Fig. 6D). A similar effect was observed with PMA applied before BAC (Tables 2, row r, 3, rows j and I, Fig. $5 D$ ). These results suggested the absence of GIRK1 but the presence of the other neuronal form, GIRK2, in GnRH neurons. Immunofluorescent staining with a validated antibody (Marron Fernandez de Velasco et al., 2017) demonstrated the presence of GIRK2 in all GnRH neurons (Fig. 7), consistent with its ubiquitous presence in most neurons (Lüscher and Slesinger, 2010). Together, these data are consistent with GIRK2/3 channels, downstream of ORL1 receptor, mediating the OFQ inhibition in $\mathrm{GnRH}$ neurons.

\section{OFQ fibers contact GnRH neurons}

To begin to identify the anatomic circuit, immunocytochemistry for OFQ and GnRH was performed. In contrast to ewes (Foradori et al., 2007), GnRH neurons in adult mice were not immunoreactive for OFQ. However, OFQ fibers were observed in the POA, where most $\mathrm{GnRH}$ cell bodies are found, and within this region some OFQ fibers were found apposed to $\mathrm{GnRH}$ fibers and cell bodies (Fig. 8). In the rat, a subpopulation of POMC neurons in the ARC is labeled with OFQ (Maolood and Meister, 2010) and POMC fibers contact GnRH neurons (Leranth et al., 1988; Simonian et al., 1999). Thus, the possibility that OFQ fibers contacting $\mathrm{GnRH}$ neurons originated from POMC neurons in the ARC was investigated. In the mouse, a subset (estimated 5-10\%) of POMC neurons was immunoreactive for OFQ (Fig. 9), but all OFQ neurons were POMC positive. POMC fibers were observed apposed to GnRH neurons in the POA (Fig. 10A-C). Notably, the POA also contained some fibers colabeled with OFQ and POMC (Fig. 10D). However, using triple immunolabeling for $\mathrm{GnRH}, \mathrm{OFQ}$, and POMC, fibers colabeled with 

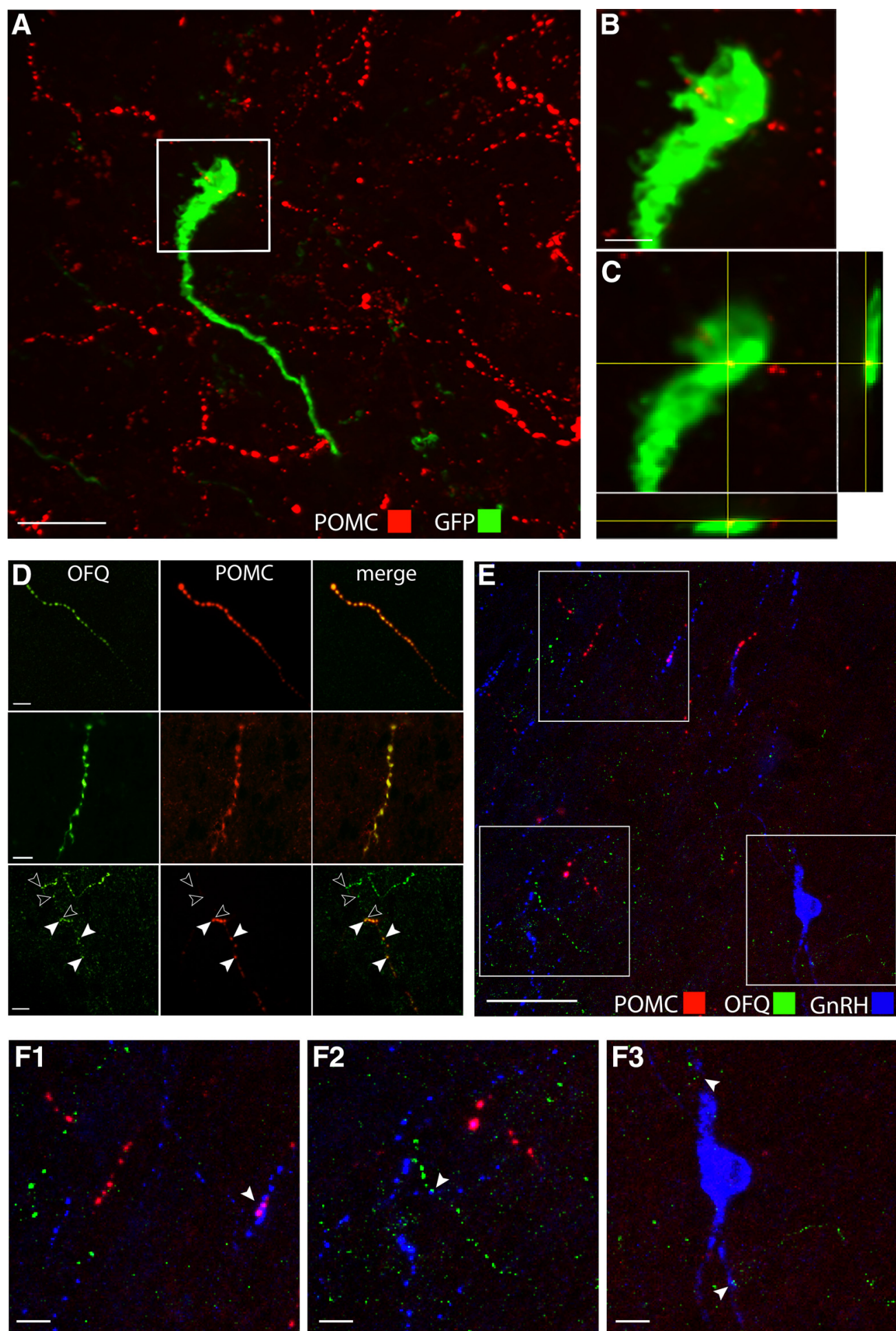

Figure 10. POMC-immunoreactive fibers contact $\mathrm{GnRH}$ neurons and POMC fibers in the POA coexpress OFQ. A-C, Representative stack of confocal images showing GnRH neurons labeled with GFP- (green) and POMC- (red) immunoreactive fibers in an adult male mouse. Scale bar, $20 \mu \mathrm{m}$. Enlarged image from boxed area in $\boldsymbol{B}$. Scale bar, $5 \mu \mathrm{m}$. $\boldsymbol{C}$, Single confocal plan from boxed area showing a POMC-immunoreactive fiber apposed to this $\mathrm{GnRH}$ cell body in the POA. $\boldsymbol{D}$, Representative confocal images showing fibers immunoreactive for OFQ and POMC in the POA. Scale bars, $10 \mu \mathrm{m}$. Note individual varicosities in the same fiber which are immunolabeled for only OFQ (single-labeled; open arrowheads, third panel) or for both OFQ and POMC (dual-labeled; filled arrowheads), suggesting that spatial localization of these peptides might occur in processes. $\boldsymbol{E}, \boldsymbol{F}$, Representative confocal image ( $Z$ projection, $\sim 10 \mu \mathrm{m}$ ) showing immunoreactivity for OFQ (green) and POMC (red) in fibers surrounding GnRH (blue) neurons in the POA. Scale bar, $50 \mu \mathrm{m}$. F1-F3, Boxed areas in $\boldsymbol{E}$ enlarged show contacts (arrowheads) between GnRH and POMC fibers (F1), between $\mathrm{GnRH}$ and OFQ fibers (F2), and near cell bodies (F3). Scale bars, $10 \mu \mathrm{m}$. 
A
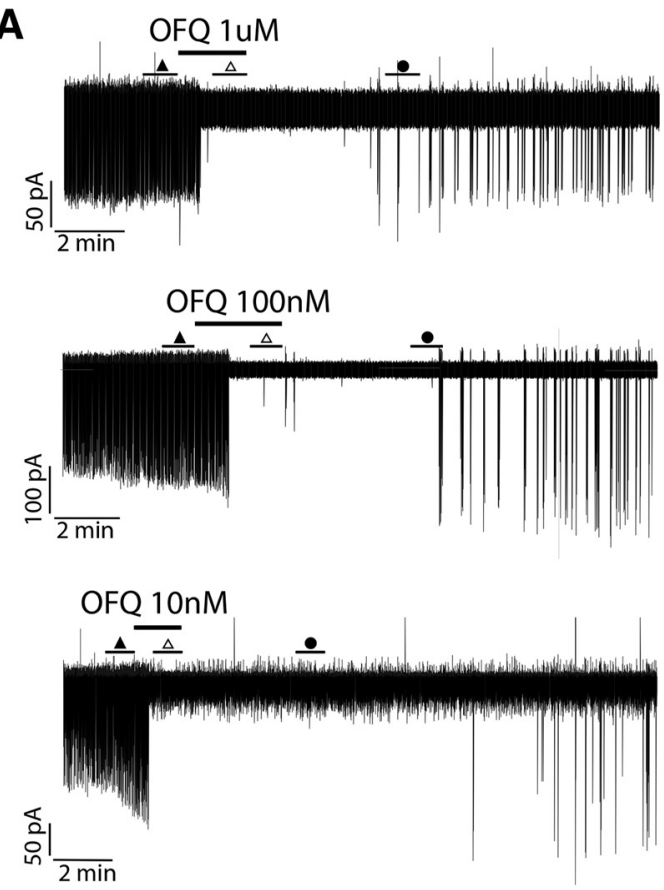

B

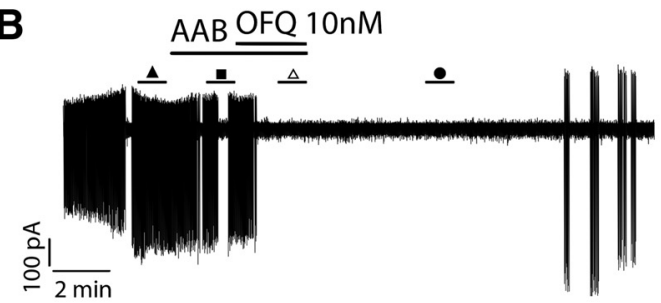

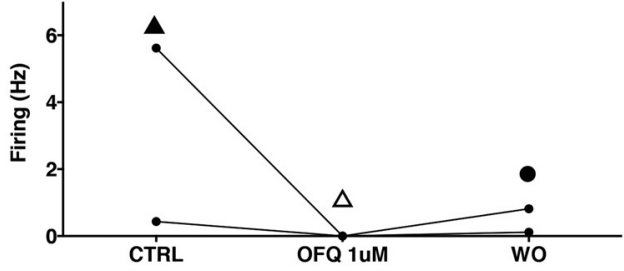
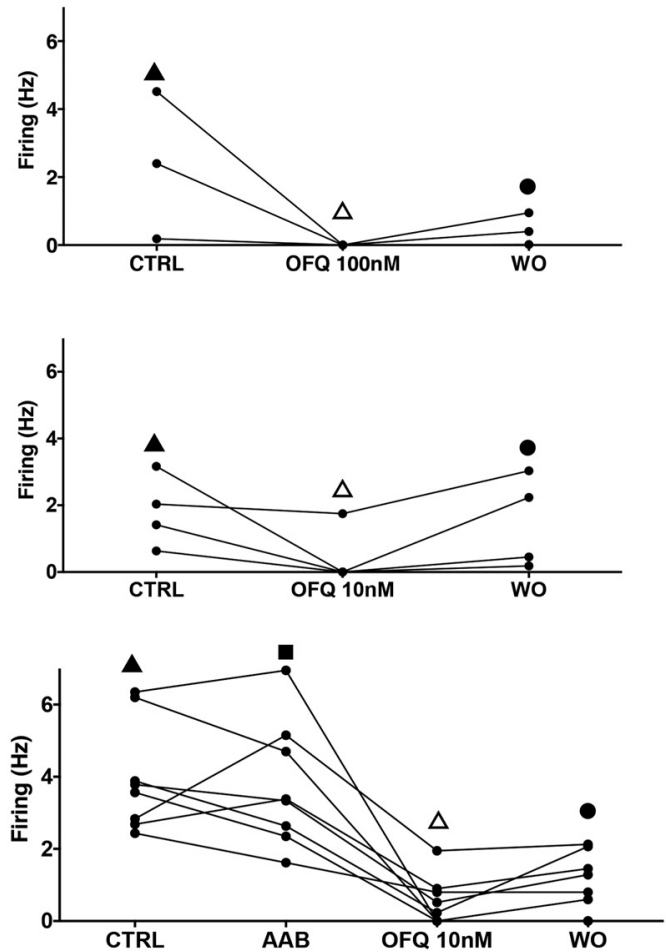

Figure 11. OFQ inhibits the GnRH neuron firing rate in acute brain slices, independent of GABAergic and glutamatergic inputs. $\boldsymbol{A}$, Left, Electrophysiological recording of adult GFP-tagged GnRH neurons showing that OFQ (1 $\mu \mathrm{m}, 100 \mathrm{~nm}$, and $10 \mathrm{~nm})$ evoked a potent decrease in $\mathrm{GnRH}$ neuron firing rate. Right, Summary data showing quantification of firing rate (in $\mathrm{Hz}$ ) in individual $\mathrm{GnRH}$ neurons tested at the different concentrations during the control (CTRL), treatment (OFQ), and washout (WO) periods. The values represent the average of $1 \mathrm{~s}$ bins for the last $1 \mathrm{~min}$ of each period identified on the traces. B, Left, OFQ (10 nM) in the presence of AABs (BIC, $20 \mu \mathrm{M}$; CNQX, $10 \mu \mathrm{M}$; D-AP5, $20 \mu \mathrm{M}$ ) still decreased GnRH neuron firing rate. Right, Summary data showing quantification of the firing rate (in $\mathrm{Hz}$ ) in individual $\mathrm{GnRH}$ neurons tested during the control (CTRL), pretreatment $(\mathrm{AAB})$, treatment $(+\mathrm{OFQ})$, and washout $(\mathrm{WO})$ periods. The values represent the average of $1 \mathrm{~s}$ bins for the last $1 \mathrm{~min}$ of each period identified on the traces.

POMC and OFQ were not found contacting GnRH neurons (Fig. 10E,F).

\section{OFQ inhibits GnRH neurons in situ, independently of GABAergic and glutamatergic inputs}

OFQ was applied at different doses to $\mathrm{GnRH}$ neurons in acute brain slices. OFQ stopped the firing in two of two cells $(N=2)$, three of three cells $(N=2)$, and two of two cells $(N=1)$ at $1 \mu \mathrm{M}, 100 \mathrm{~nm}$, and $10 \mathrm{~nm}$, respectively (Fig. $11 A$ ). After the blockade of GABAergic and glutamatergic excitatory inputs with $\mathrm{AAB}(\mathrm{BIC}, 20 \mu \mathrm{M}$; CNQX, $10 \mu \mathrm{M}$; D-AP5, $20 \mu \mathrm{M})$, OFQ (10 nM) still inhibited eight of nine cells, five of them being stopped $(N=3$; Fig. $11 B)$. Of the 12 cells that stopped, without $(n=7)$ or with $\mathrm{AAB}(n=5)$, the average time to regained firing was after $9.0 \pm 1.3 \mathrm{~min}$ $(N=8)$. OFQ (10 nM) suppressed kisspeptin-10 (100 nM)-evoked excitation (Fig. 12A-C; four of four cells tested; $N=4$ ) but did not terminate it. The OFQ suppression was partially prevented by UFP-101 (500 nм; $N=3$ ), supporting the role of ORL1 (Fig. 12B-D). These data support a role for OFQ as a modulator of $\mathrm{GnRH}$ neuron neuronal activity but rule out its function as the terminator of kisspeptin-induced excitation.

\section{Discussion}

The present study investigated the neuromodulation of $\mathrm{GnRH}$ neurons by OFQ in the mouse. We report that OFQ strongly inhibits spontaneous $\mathrm{GnRH}$ neuronal activity and can repress kisspeptin-evoked excitation. The inhibition, independent of GABAergic and glutamatergic inputs, is mainly mediated by ORL1, $\mathrm{G}_{\mathrm{i} / \mathrm{o}}$-protein-coupled receptor, and the subsequent activation of GIRK channels. In vivo, OFQ-immunopositive fibers were found contacting $\mathrm{GnRH}$ neurons. Together, these data suggest that OFQ can downregulate the reproductive axis. 
A
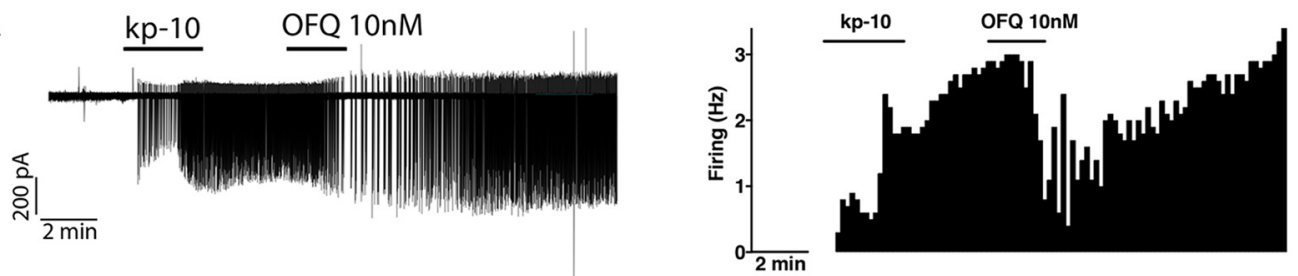

B
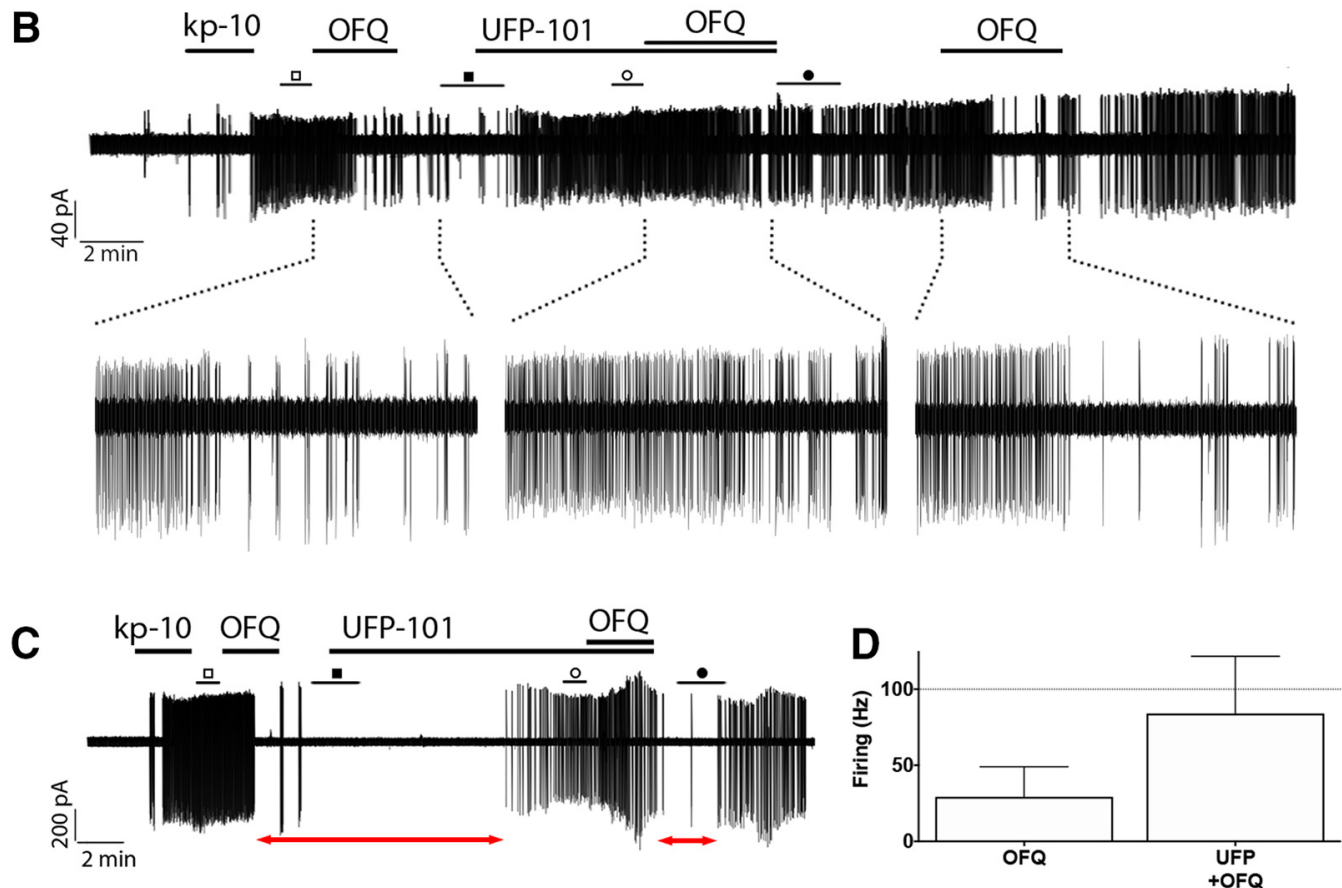

$\mathbf{E}$

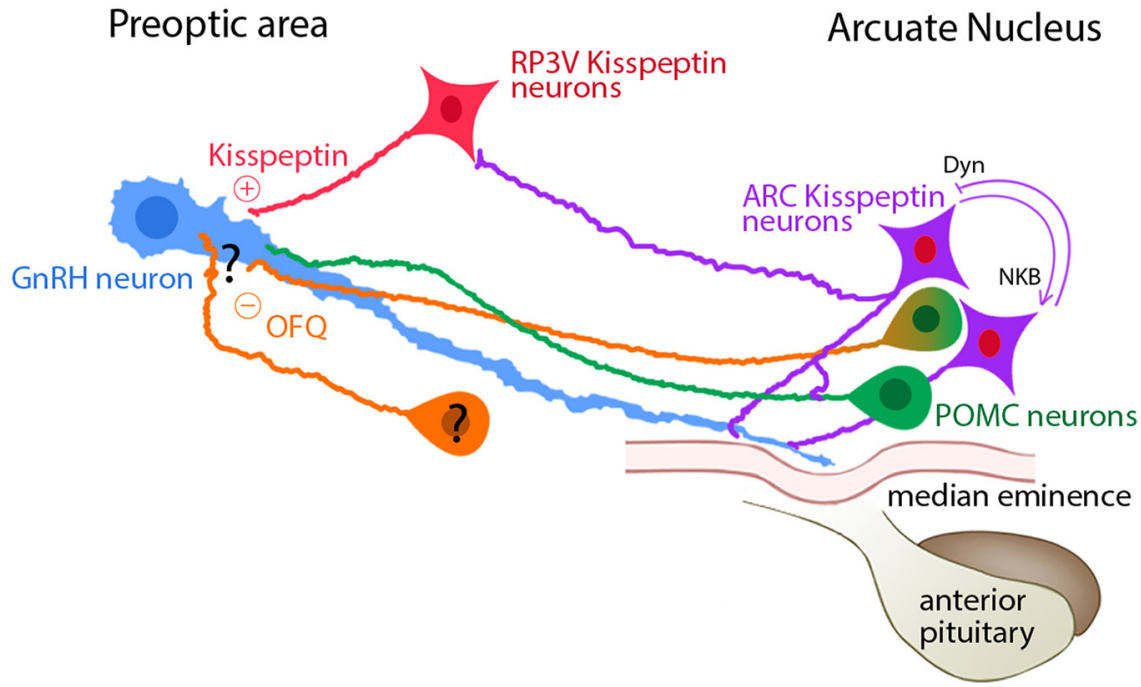

Figure 12. $\mathrm{OFQ}$ as a new player in the $\mathrm{ARC}$ regulation of $\mathrm{GnRH}$ neurons. $\boldsymbol{A}$, Left, Electrophysiological recording of an adult GFP-tagged GnRH neuron showing OFQ (10 nm) suppressed the firing rate of kisspeptin-10 (kp-10; 100 nm)-activated GnRH neurons. Right, Corresponding periodogram illustrating the changes in $\mathrm{GnRH}$ neuron firing rate (in $\mathrm{Hz}$ ) over time (i.e., the increase in firing rate induced by $\mathrm{kp}-10$ and its suppression by OFQ). The bars represent the instant frequency in $10 \mathrm{~s}$ bins. $\boldsymbol{B}$, Electrophysiological recording of another adult GFP-tagged GnRH neuron showing OFQ (10 nm) suppressed the firing rate of kp-10 (100 nM)-activated $\mathrm{GnRH}$ neurons. The inhibition evoked by OFQ was partially antagonized by UFP-101 (500 nM) but was reestablished by a second application of OFQ after the washout of UFP-101. C, Electrophysiological recording of a third adult GFP-tagged GnRH neuron showing the partial antagonism of OFQ by UFP-101. Note that, without UFP-101, the OFQ evoked a pause in the tonic firing for $\sim 11$ min (red arrow, on the left), while with UFP-101 the pause was $\sim 2.5 \mathrm{~min}$ (red arrow, on the right; i.e., an approximately four times faster recovery despite being further from the initial kp-10 application. $\boldsymbol{D}$, Quantification of the OFQ inhibition, before (square) and after 


\section{continued}

(circle) the application of UPF-101. The values represent the firing rate 4 min after OFQ or UFP-101 plus OFQ application, normalized to the firing rate in the last minute of aCSF application before application of OFQ (empty square) or UFP-101 before UFP-101 plus OFQ (empty circle) application, respectively. E, Diagram representing where OFQ stands within the already established connectivity around GnRH neurons. GnRH neuron (blue) receive excitatory inputs from RP3V kisspeptin neurons (red) at the soma. ARC kisspeptin neurons (purple), autoregulated via a neurokinin B and dynorphin loop, contact $\mathrm{GnRH}$ neuronal processes around the median eminence. Both kisspeptin neuronal populations are linked via ARC $\rightarrow$ RP3V connections. POMC neurons (green) contact GnRH neurons (Leranth et al., 1988; Simonian et al., 1999). ARC kisspeptin neurons contact POMC neurons (Fu and van den Pol, 2010; Nestor et al., 2016). OFQ fibers (orange), possibly originating from a subpopulation of POMC neurons and/or another unidentified neuronal population, contact GnRH neurons, providing an inhibitory signal.

OFQ inhibits $\mathrm{GnRH}$ secretion from mediobasal fragments (Dhandapani and Brann, 2002; An et al., 2005) or in vivo [push-pull (An et al., 2005); intracerebroventricular (An et al., 2005, 2009)]. The in vivo inhibition is ORL1 dependent (An et al., 2005, 2009). However, since the receptor is widely distributed in the brain (Ikeda et al., 1998; Neal et al., 1999; Houtani et al., 2000) and even in the hypothalamus (Chen et al., 2017), how OFQ inhibited $\mathrm{GnRH}$ secretion was unknown. Evidence for indirect actions of OFQ on GnRH neurons exist, including the following: (1) transcripts for ORL1 were not detected in an immortalized GnRH cell line obtained from mouse (Dhandapani and Brann, 2002); and (2) the stimulatory effect of ORL1 antagonists on POA GnRH release were mediated by glutamate in male rats (An et al., 2008). However, our calcium imaging and patch-clamp data indicate a direct action of OFQ onto GnRH neurons since OFQ inhibited $\mathrm{GnRH}$ neuronal activity while both GABAergic and glutamatergic inputs were disrupted. Notably, GnRH neuronal activity does not require these two excitatory inputs (Constantin et al., 2010; Lee et al., 2012), but they are the main excitatory inputs in acute brain slices (Iremonger et al., 2010; Herbison and Moenter, 2011) and largely contribute to $\mathrm{GnRH}$ neuronal activity in nasal explants (Constantin et al., 2010). Inhibition of GnRH neuronal activity by OFQ is consistent with previous data showing OFQ hyperpolarized GnRH neurons from OVX guinea pig through an inwardly rectifying potassium current (Wagner et al., 1998). A direct action of OFQ on GnRH neurons is further supported by our findings of ORL1 transcript in GnRH neurons and OFQ fibers contacting $\mathrm{GnRH}$ neurons.

Examination of the signaling pathway demonstrated that the OFQ inhibition was ORL1 mediated. ORL1 coupling to $\mathrm{G}_{\mathrm{i} / \mathrm{o}}$-type G-protein (Reinscheid et al., 1995; Ikeda et al., 1997) was confirmed in $\mathrm{GnRH}$ neurons treated with PTX. OFQ-induced inhibition could occur through two signaling pathways: a decrease of cyclic adenosine monophosphate and/or the activation of GIRK channels (for review, see Al-Hasani and Bruchas, 2011). The data obtained using IBMX and FSK clearly indicate that the OFQ-induced inhibition of GnRH neuron activity occurs without a decrease of cAMP. In fact, previous studies from our laboratory have already shown that a decrease of cAMP does not affect GnRH neuronal activity (Constantin and Wray, 2008, 2016), while the activation of Csand $\mathrm{Ba}$-sensitive channels inhibits $\mathrm{GnRH}$ neurons (Klenke et al., 2010; Constantin and Wray, 2016).

Most neurons express GIRK1, GIRK2, and GIRK3 (Lüscher and Slesinger, 2010). Transcripts for both GIRK1
( $\mathrm{K}_{\mathrm{ir}} 3.1, \mathrm{Kcnj3}$; Constantin and Wray, 2016) and GIRK3

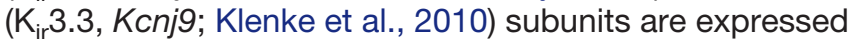
in $\mathrm{GnRH}$ neurons. Neither GIRK1 nor GIRK3 subunits can form homotetrameric functional GIRK channels but can assemble into functional heterotetramers (Lüscher and Slesinger, 2010). The sensitivity of the OFQ inhibition to Cs and $\mathrm{Ba}$, but not to TPNQ, naringin, or ML297, indicated a different subunit composition of the GIRK channels associated with ORL1 (Kobayashi et al., 2011) in GnRH cells and suggested the presence of GIRK2 subunits in their GIRK channels. To further test this hypothesis, baclofen, a $\mathrm{GABA}_{\mathrm{B}}$ agonist, was used to activate GIRK channels (Kahanovitch et al., 2017). Although $\mathrm{GABA}_{B}$ can use two-pore domain potassium channels (Bushell et al., 2002; Deng et al., 2009), the literature supports the role of $\mathrm{GABA}_{B}$ using inwardly rectifying potassium currents in GnRH neurons (Wagner et al., 1998; Zhang et al., 2009). BAC-induced inhibition was also insensitive to TPNQ. This observation is supported by a study showing that GIRK channels coupled to ORL1, at least partially, overlap the GABA $A_{B}$-coupled GIRK channel pool (Wagner et al., 1998). Since no other GIRK-specific blockers are available, an alternative route to test GIRK2 involvement in OFQ signaling via ORL1 was used. Protein kinase $C$ is known to phosphorylate GIRK channels, GIRK2 included (Adney et al., 2015), and to desensitize GIRK-mediated currents (Stevens et al., 1999; Lüscher and Slesinger, 2010). Together with our earlier data, the lack of OFQ inhibition after the application of a PKC activator and the immunoreactivity of $\mathrm{GnRH}$ neurons for GIRK2 show that OFQ inhibition of $\mathrm{GnRH}$ neurons is mediated by GIRK channels containing GIRK2/3 subunits.

OFQ fibers were identified contacting $\mathrm{GnRH}$ fibers and cell bodies in the POA, supporting a direct effect of OFQ on $\mathrm{GnRH}$ cells. One could argue that the contacts on $\mathrm{GnRH}$ fibers are irrelevant to the modulation of $\mathrm{GnRH}$ neuron firing; however, GIRK channels localize to specific subcellular compartments (Kulik et al., 2006). GIRK2 splice variants exhibit different subcellular distribution and might impact the integration of afferent inhibitory inputs (Marron Fernandez de Velasco et al., 2017). In addition, $\mathrm{GABA}_{\mathrm{B}}$ inhibition in $\mathrm{GnRH}$ neurons is largely lost in preparations that sever processes (Constantin et al., 2012). GnRH neuronal cell bodies were not immunolabeled for OFQ in the adult mouse. This is in contrast to data from the sheep where virtually all $\mathrm{GnRH}$ neurons express OFQ in ewes (Foradori et al., 2007). GnRH neuron immunoreactivity for OFQ in sheep might be a species-specific and lasting vestige of their embryonic origin. Indeed, the liter- 
ature shows that OFQ is highly expressed in early development (Ikeda et al., 1998; Neal et al., 2001) and is involved in the olfactory placode formation (Lleras-Forero et al., 2013) where GnRH cells originate (SchwanzelFukuda and Pfaff, 1989; Wray et al., 1989a). Alternatively, the active transport of OFQ down the axon could have precluded the identification of OFQ-labeled GnRH neuronal cell bodies in the mouse. However, two facts seem to argue against this: (1) the median eminence, which contains a high density of $\mathrm{GnRH}$ neuronal fibers, was not labeled for OFQ; and (2) cell bodies immunopositive for OFQ were present in the $A R C$, in agreement with data from rat and sheep (Maolood and Meister, 2010; Nestor et al., 2013).

In the current model of GnRH pulsatility, ARC kisspeptin neurons exhibit autonomous rhythmicity, driven by neurokinin $B$ and autocrine inhibition by dynorphin $A$, and lead to the excitation of $\mathrm{GnRH}$ neurons (Mittelman-Smith et al., 2012; Navarro, 2012; Goodman et al., 2013). Based on the long-lasting response to kisspeptin that has been recorded in $\mathrm{GnRH}$ neurons after exogenous application of kisspeptin-10 (Han et al., 2005; Constantin et al., 2009, 2012) or electrical stimulation of AVPV fibers contacting $\mathrm{GnRH}$ neurons (i.e., evoked release of endogenous kisspeptin; Liu et al., 2011), it is reasonable to assume that $\mathrm{GnRH}$ neurons do not release an autocrine inhibitor and, therefore, require a third partner to return their electrical activity to baseline. The cell type/neuropeptide required for this is unknown. The ARC is central to negative feedback (Xu et al., 2011; Yeo and Herbison, 2014), and POMC neurons expressing $\mathrm{ER} \alpha$ and progesterone receptor have been implicated in this process (Lagrange et al., 1995; Xu et al., 2011; Nestor et al., 2013); however, the mechanism remains unknown. The presence of OFQ neurons in the $A R C$ whose expression is upregulated by estradiol (Sanathara et al., 2014), combined with the ability of OFQ to directly suppress $\mathrm{GnRH}$ excitation triggered by kisspeptin-10, points to ARC cells expressing OFQ that communicate to $\mathrm{GnRH}$ cells as a viable candidate. The POMC gene belongs to the opioid/orphanin gene family (Navarro et al., 2016) and POMC and OFQ share processing enzymes (Allen et al., 2001). As such, the coexpression of OFQ and POMC already described in the rat and sheep (Maolood and Meister, 2010; Nestor et al., 2013), was now observed in the mouse. Despite the presence of OFQ and POMC fibers in the POA and the identification of colabeled fibers in this region, colabeled fibers were not detected in contact with $\mathrm{GnRH}$ neurons. Thus, afferents from another OFQ-positive neuronal population cannot be excluded (Fig. 12E). However, one explanation for not detecting colabeled fibers in contact with $\mathrm{GnRH}$ neurons might be the paucity of the OFQ/POMC contacts associated with the cell sampling. Another explanation might be differential routing of the neuropeptides into different processes, as seen in vasopressin neurons (Landry et al., 2003) and neurons expressing RFamide-related peptides (Yano et al., 2003). Thus, the exact identity of the source of OPQ fibers contacting $\mathrm{GnRH}$ neurons warrants further investigation.
In summary, using calcium imaging, immunohistochemistry, and electrophysiology, we have confirmed that OFQ can inhibit GnRH neurons and suppress, but not end, kisspeptin activation of $\mathrm{GnRH}$ neurons. Together, these results bring into light a potent neuromodulator of $\mathrm{GnRH}$ neurons in the mouse and contribute to our knowledge of the neuronal network upstream of $\mathrm{GnRH}$ neurons.

\section{References}

Adney SK, Ha J, Meng XY, Kawano T, Logothetis DE (2015) A critical gating switch at a modulatory site in neuronal $\mathrm{K}_{\mathrm{ir}} 3$ channels. $J$ Neurosci 35:14397-14405. CrossRef Medline

Al-Hasani R, Bruchas MR (2011) Molecular mechanisms of opioid receptor-dependent signaling and behavior. Anesthesiology 115: 1363-1381. CrossRef Medline

Allen RG, Peng B, Pellegrino MJ, Miller ED, Grandy DK, Lundblad JR, Washburn CL, Pintar JE (2001) Altered processing of pro-orphanin $\mathrm{FQ}$ /nociceptin and pro-opiomelanocortin-derived peptides in the brains of mice expressing defective prohormone convertase 2. J Neurosci 21:5864-5870. Medline

An XF, Chen HP, Ma SL, Feng Y, Hao JW, Chen BY (2005) Involvement of nociceptin/orphanin $F Q$ in release of hypothalamic $\mathrm{GnRH}$ mediated by ORL1 receptor in ovariectomized rats. Acta Pharmacol Sin 26:1039-1044. CrossRef Medline

An XF, Yu JY, Feng Y, Chen BY, Zhang SL (2007) Role of hypothalamus nociceptin/orphanin FQ in pre-ovulatory luteinizing hormone surge of estrogen and progesterone-primed, ovariectomized rats. Acta Pharmacol Sin 28:1189-1197. CrossRef Medline

An XF, Niu YF, Ten SC, Liu JS, Feng H, He M, Shen XJ (2008) Orphanin $F Q$ and glutamate connection in the regulation of gonadotropin-releasing hormone secretion in the preoptic area of conscious male rats. Neurosci Lett 440:109-112. CrossRef Medline

An XF, He M, Feng Y, Feng H, Yu JY (2009) Central administration of Orphanin FQ inhibits GnRH secretion by ORL1 receptor in the median eminence of freely moving ovariectomized rats. Neurosci Bull 25:1-6. CrossRef Medline

Bosch MA, Tonsfeldt KJ, Rønnekleiv OK (2013) mRNA expression of ion channels in $\mathrm{GnRH}$ neurons: subtype-specific regulation by 17 $\beta$-estradiol. Mol Cell Endocrinol 367:85-97. CrossRef Medline

Bushell T, Clarke C, Mathie A, Robertson B (2002) Pharmacological characterization of a non-inactivating outward current observed in mouse cerebellar Purkinje neurones. Br J Pharmacol 135:705-712. CrossRef Medline

Calo G, Rizzi A, Rizzi D, Bigoni R, Guerrini R, Marzola G, Marti M, McDonald J, Morari M, Lambert DG, Salvadori S, Regoli D (2002) [Nphe1,Arg14,Lys15]nociceptin-NH2, a novel potent and selective antagonist of the nociceptin/orphanin FQ receptor. Br J Pharmacol 136:303-311. CrossRef Medline

Campbell JN, Macosko EZ, Fenselau H, Pers TH, Lyubetskaya A, Tenen D, Goldman M, Verstegen AM, Resch JM, McCarroll SA, Rosen ED, Lowell BB, Tsai LT (2017) A molecular census of arcuate hypothalamus and median eminence cell types. Nat Neurosci 20:484-496. CrossRef Medline

Chen R, Wu X, Jiang L, Zhang Y (2017) Single-cell RNA-seq reveals hypothalamic cell diversity. Cell Rep 18:3227-3241. CrossRef Medline

Chen Y, Sommer C (2006) Nociceptin and its receptor in rat dorsal root ganglion neurons in neuropathic and inflammatory pain models: implications on pain processing. J Peripher Nerv Syst 11:232240. CrossRef Medline

Chronwall BM (1985) Anatomy and physiology of the neuroendocrine arcuate nucleus. Peptides 6 [Suppl 2]:1-11. Medline

Chu Z, Moenter SM (2005) Endogenous activation of metabotropic glutamate receptors modulates GABAergic transmission to gonadotropin-releasing hormone neurons and alters their firing rate: a possible local feedback circuit. J Neurosci 25:5740-5749. CrossRef Medline 
Constantin S, Wray S (2008) Gonadotropin-releasing hormone-1 neuronal activity is independent of cyclic nucleotide-gated channels. Endocrinology 149:279-290. CrossRef Medline

Constantin S, Wray S (2016) Galanin activates G-protein gated inwardly rectifying potassium channels and suppresses kisspeptin-10 activation of GnRH neurons. Endocrinology 157: 3197-3212. CrossRef Medline

Constantin S, Caligioni CS, Stojilkovic S, Wray S (2009) Kisspeptin-10 facilitates a plasma membrane-driven calcium oscillator in gonadotropin-releasing hormone-1 neurons. Endocrinology 150:1400-1412. CrossRef Medline

Constantin S, Klenke U, Wray S (2010) The calcium oscillator of $\mathrm{GnRH}-1$ neurons is developmentally regulated. Endocrinology 151:3863-3873. CrossRef Medline

Constantin S, Piet R, Iremonger K, Yeo SH, Clarkson J, Porteous R, Herbison AE (2012) GnRH neuron firing and response to GABA in vitro depend on acute brain slice thickness and orientation. Endocrinology 153:3758-3769. CrossRef

Constantin S, Iremonger KJ, Herbison AE (2013) In vivo recordings of $\mathrm{GnRH}$ neuron firing reveal heterogeneity and dependence upon $\mathrm{GABA}_{\mathrm{A}}$ receptor signaling. J Neurosci 33:9394-9401. CrossRef Medline

Deng PY, Xiao Z, Yang C, Rojanathammanee L, Grisanti L, Watt J, Geiger JD, Liu R, Porter JE, Lei S (2009) GABA(B) receptor activation inhibits neuronal excitability and spatial learning in the entorhinal cortex by activating TREK-2 K+ channels. Neuron 63: 230-243. CrossRef Medline

Dhandapani KM, Brann DW (2002) Orphanin FQ inhibits GnRH secretion from rat hypothalamic fragments but not GT1-7 neurons. Neuroreport 13:1247-1249. Medline

Dumalska I, Wu M, Morozova E, Liu R, van den Pol A, Alreja M (2008) Excitatory effects of the puberty-initiating peptide kisspeptin and group I metabotropic glutamate receptor agonists differentiate two distinct subpopulations of gonadotropin-releasing hormone neurons. J Neurosci 28:8003-8013. CrossRef

Elkabes S, Loh YP, Nieburgs A, Wray S (1989) Prenatal ontogenesis of pro-opiomelanocortin in the mouse central nervous system and pituitary gland: an in situ hybridization and immunocytochemical study. Brain Res Dev Brain Res 46:85-95. CrossRef

Foradori CD, Amstalden M, Coolen LM, Singh SR, McManus CJ, Handa RJ, Goodman RL, Lehman MN (2007) Orphanin FQ: evidence for a role in the control of the reproductive neuroendocrine system. Endocrinology 148:4993-5001. CrossRef Medline

Fox SR, Harlan RE, Shivers BD, Pfaff DW (1990) Chemical characterization of neuroendocrine targets for progesterone in the female rat brain and pituitary. Neuroendocrinology 51:276-283. CrossRef Medline

Fu LY, van den Pol AN (2010) Kisspeptin directly excites anorexigenic proopiomelanocortin neurons but inhibits orexigenic neuropeptide $\mathrm{Y}$ cells by an indirect synaptic mechanism. J Neurosci 30:10205-10219. CrossRef Medline

Fueshko S, Wray S (1994) LHRH cells migrate on peripherin fibers in embryonic olfactory explant cultures: an in vitro model for neurophilic neuronal migration. Dev Biol 166:331-348. CrossRef

Giacobini P, Kopin AS, Beart PM, Mercer LD, Fasolo A, Wray S (2004) Cholecystokinin modulates migration of gonadotropinreleasing hormone-1 neurons. J Neurosci 24:4737-4748. CrossRef Medline

Glanowska KM, Moenter SM (2015) Differential regulation of GnRH secretion in the preoptic area (POA) and the median eminence (ME) in male mice. Endocrinology 156:231-241. CrossRef Medline

Goodman RL, Hileman SM, Nestor CC, Porter KL, Connors JM, Hardy SL, Millar RP, Cernea M, Coolen LM, Lehman MN (2013) Kisspeptin, neurokinin B, and dynorphin act in the arcuate nucleus to control activity of the GnRH pulse generator in ewes. Endocrinology 154:4259-4269. CrossRef Medline

Han SK, Gottsch ML, Lee KJ, Popa SM, Smith JT, Jakawich SK, Clifton DK, Steiner RA, Herbison AE (2005) Activation of gonadotropin-releasing hormone neurons by kisspeptin as a neu- roendocrine switch for the onset of puberty. J Neurosci 25:1134911356. CrossRef Medline

Herbison AE, Moenter SM (2011) Depolarising and hyperpolarising actions of GABA(A) receptor activation on gonadotrophinreleasing hormone neurones: towards an emerging consensus. J Neuroendocrinol 23:557-569. CrossRef Medline

Hoffman GE, Le WW, Sita LV (2008) The importance of titrating antibodies for immunocytochemical methods. Curr Protoc Neurosci Chapter 2:Unit 2.12.

Houtani T, Nishi M, Takeshima H, Sato K, Sakuma S, Kakimoto S, Ueyama T, Noda T, Sugimoto T (2000) Distribution of nociceptin/ orphanin FQ precursor protein and receptor in brain and spinal cord: a study using in situ hybridization and X-gal histochemistry in receptor-deficient mice. J Comp Neurol 424:489-508. Medline

Ikeda K, Kobayashi K, Kobayashi T, Ichikawa T, Kumanishi T, Kishida H, Yano R, Manabe T (1997) Functional coupling of the nociceptin/ orphanin FQ receptor with the G-protein-activated K+ (GIRK) channel. Brain Res Mol Brain Res 45:117-126. Medline

Ikeda K, Watanabe M, Ichikawa T, Kobayashi T, Yano R, Kumanishi $\mathrm{T}$ (1998) Distribution of prepro-nociceptin/orphanin FQ mRNA and its receptor mRNA in developing and adult mouse central nervous systems. J Comp Neurol 399:139-151. Medline

Iremonger K, Constantin S, Liu X, Herbison A (2010) Glutamate regulation of $\mathrm{GnRH}$ neuron excitability. Brain Res 1364:35-43. CrossRef Medline

Iremonger KJ, Porteous R, Herbison AE (2017) Spike and neuropeptide-dependent mechanisms control $\mathrm{GnRH}$ neuron nerve terminal $\mathrm{Ca}^{2+}$ over diverse time scales. J Neurosci 37:3342-3351. CrossRef

Jiao Y, Sun Z, Lee T, Fusco FR, Kimble TD, Meade CA, Cuthbertson S, Reiner A (1999) A simple and sensitive antigen retrieval method for free-floating and slide-mounted tissue sections. J Neurosci Methods 93:149-162. Medline

Jirikowski GF, Merchenthaler I, Rieger GE, Stumpf WE (1986) Estradiol target sites immunoreactive for beta-endorphin in the arcuate nucleus of rat and mouse hypothalamus. Neurosci Lett 65:121126. Medline

Johnson M, Zaretskaya I, Raytselis Y, Merezhuk Y, McGinnis S, Madden TL (2008) NCBI BLAST: a better web interface. Nucleic Acids Res 36:W5-W9. CrossRef Medline

Kahanovitch U, Berlin S, Dascal N (2017) Collision coupling in the GABAB receptor-G protein-GIRK signaling cascade. FEBS Lett 591:2816-2825.

Kaufmann K, Romaine I, Days E, Pascual C, Malik A, Yang L, Zou B, Du Y, Sliwoski G, Morrison RD, Denton J, Niswender CM, Daniels JS, Sulikowski GA, Xie XS, Lindsley CW, Weaver CD (2013) ML297 (VU0456810), the first potent and selective activator of the GIRK potassium channel, displays antiepileptic properties in mice. ACS Chem Neurosci 4:1278-1286. CrossRef Medline

Klenke U, Constantin S, Wray S (2010) Neuropeptide Y directly inhibits neuronal activity in a subpopulation of gonadotropinreleasing hormone-1 neurons via Y1 receptors. Endocrinology 151:2736-2746. CrossRef

Kobayashi T, Washiyama K, Ikeda K (2011) Inhibition of G proteinactivated inwardly rectifying $\mathrm{K}+$ channels by different classes of antidepressants. PLoS One 6:e28208. CrossRef

Kramer PR (2002) cDNA library construction from single cells. Curr Protoc Neurosci Chapter 4:Unit 4.27.

Kulik A, Vida I, Fukazawa Y, Guetg N, Kasugai Y, Marker CL, Rigato F, Bettler B, Wickman K, Frotscher M, Shigemoto R (2006) Compartment-dependent colocalization of $\mathrm{K}_{\mathrm{ir}} 3.2$-containing $\mathrm{K}^{+}$ channels and $\mathrm{GABA}_{\mathrm{B}}$ receptors in hippocampal pyramidal cells. $J$ Neurosci 26:4289-4297. CrossRef Medline

Lagrange AH, Rønnekleiv OK, Kelly MJ (1995) Estradiol-17 beta and mu-opioid peptides rapidly hyperpolarize $\mathrm{GnRH}$ neurons: a cellular mechanism of negative feedback? Endocrinology 136:2341-2344. CrossRef Medline

Landry M, Vila-Porcile E, Hökfelt T, Calas A (2003) Differential routing of coexisting neuropeptides in vasopressin neurons. Eur J Neurosci 17:579-589. CrossRef 
Lee K, Liu X, Herbison AE (2012) Burst firing in gonadotrophinreleasing hormone neurones does not require ionotrophic GABA or glutamate receptor activation. J Neuroendocrinol 24:1476-1483. CrossRef Medline

Leranth C, MacLusky NJ, Shanabrough M, Naftolin F (1988) Immunohistochemical evidence for synaptic connections between proopiomelanocortin-immunoreactive axons and $\mathrm{LH}-\mathrm{RH}$ neurons in the preoptic area of the rat. Brain Res 449:167-176. Medline

Liu X, Porteous R, d'Anglemont de Tassigny X, Colledge WH, Millar R, Petersen SL, Herbison AE (2011) Frequency-dependent recruitment of fast amino acid and slow neuropeptide neurotransmitter release controls gonadotropin-releasing hormone neuron excitability. J Neurosci 31:2421-2430. CrossRef Medline

Llamosas N, Ugedo L, Torrecilla M (2017) Inactivation of GIRK channels weakens the pre- and postsynaptic inhibitory activity in dorsal raphe neurons. Physiol Rep 5:e13141.

Lleras-Forero L, Tambalo M, Christophorou N, Chambers D, Houart C, Streit A (2013) Neuropeptides: developmental signals in placode progenitor formation. Dev Cell 26:195-203. CrossRef Medline

Lüscher C, Slesinger PA (2010) Emerging roles for G protein-gated inwardly rectifying potassium (GIRK) channels in health and disease. Nat Rev Neurosci 11:301-315. CrossRef

Maolood N, Meister B (2010) Nociceptin/orphanin FQ peptide in hypothalamic neurones associated with the control of feeding behaviour. J Neuroendocrinol 22:75-82. CrossRef Medline

Marron Fernandez de Velasco E, Zhang L, N Vo B, Tipps M, Farris S, Xia Z, Anderson A, Carlblom N, Weaver CD, Dudek SM, Wickman K (2017) GIRK2 splice variants and neuronal G protein-gated K(+) channels: implications for channel function and behavior. Sci Rep 7:1639.

Mezey E, Kiss JZ, Mueller GP, Eskay R, O’Donohue TL, Palkovits M (1985) Distribution of the pro-opiomelanocortin derived peptides, adrenocorticotrope hormone, alpha-melanocyte-stimulating hormone and beta-endorphin (ACTH, alpha-MSH, beta-END) in the rat hypothalamus. Brain Res 328:341-347. Medline

Mittelman-Smith MA, Williams H, Krajewski-Hall SJ, Lai J, Ciofi P, McMullen NT, Rance NE (2012) Arcuate kisspeptin/neurokinin $\mathrm{B} /$ dynorphin (KNDy) neurons mediate the estrogen suppression of gonadotropin secretion and body weight. Endocrinology 153: 2800-2812. CrossRef Medline

Mollereau C, Mouledous L (2000) Tissue distribution of the opioid receptor-like (ORL1) receptor. Peptides 21:907-917. Medline

Navarro S, Soletto L, Puchol S, Rotllant J, Soengas JL, CerdáReverter JM (2016) 60 YEARS OF POMC: POMC: an evolutionary perspective. J Mol Endocrinol 56:T113-T118. CrossRef Medline

Navarro VM (2012) New insights into the control of pulsatile GnRH release: the role of Kiss1/neurokinin B neurons. Front Endocrinol 3:48. CrossRef Medline

Neal CR Jr, Mansour A, Reinscheid R, Nothacker HP, Civelli O, Watson SJ Jr (1999) Localization of orphanin FQ (nociceptin) peptide and messenger RNA in the central nervous system of the rat. J Comp Neurol 406:503-547. Medline

Neal CR Jr, Akil H, Watson SJ Jr (2001) Expression of orphanin FQ and the opioid receptor-like (ORL1) receptor in the developing human and rat brain. J Chem Neuroanat 22:219-249. CrossRef

Nestor CC, Coolen LM, Nesselrod GL, Valent M, Connors JM, Hileman SM, Cheng G, Lehman MN, Goodman RL (2013) Evidence that orphanin FQ mediates progesterone negative feedback in the ewe. Endocrinology 154:4249-4258. CrossRef Medline

Nestor CC, Qiu J, Padilla SL, Zhang C, Bosch MA, Fan W, Aicher SA, Palmiter RD, Rønnekleiv OK, Kelly MJ (2016) Optogenetic stimulation of arcuate nucleus Kiss1 neurons reveals a steroiddependent glutamatergic input to POMC and AgRP neurons in male mice. Mol Endocrinol 30:630-644. CrossRef Medline

Nockemann D, Rouault M, Labuz D, Hublitz P, McKnelly K, Reis FC, Stein C, Heppenstall PA (2013) The $K(+)$ channel GIRK2 is both necessary and sufficient for peripheral opioid-mediated analgesia. EMBO Mol Med 5:1263-1277. CrossRef
Reinscheid RK, Nothacker HP, Bourson A, Ardati A, Henningsen RA, Bunzow JR, Grandy DK, Langen H, Monsma FJ Jr, Civelli O (1995) Orphanin FQ: a neuropeptide that activates an opioidlike G protein-coupled receptor. Science 270:792-794. Medline

Roa J (2013) Role of GnRH neurons and their neuronal afferents as key integrators between food intake regulatory signals and the control of reproduction. Int J Endocrinol 2013:518046. CrossRef Medline

Roa J, Herbison AE (2012) Direct regulation of GnRH neuron excitability by arcuate nucleus POMC and NPY neuron neuropeptides in female mice. Endocrinology 153:5587-5599. CrossRef Medline

Sanathara NM, Moreas J, Mahavongtrakul M, Sinchak K (2014) Estradiol upregulates progesterone receptor and orphanin FQ colocalization in arcuate nucleus neurons and opioid receptor-like receptor-1 expression in proopiomelanocortin neurons that project to the medial preoptic nucleus in the female rat. Neuroendocrinology 100:103-118. CrossRef Medline

Schwanzel-Fukuda M, Pfaff DW (1989) Origin of luteinizing hormonereleasing hormone neurons. Nature 338:161-164. CrossRef Medline

Shindler KS, Roth KA (1996) Double immunofluorescent staining using two unconjugated primary antisera raised in the same species. J Histochem Cytochem 44:1331-1335. Medline

Simonian SX, Spratt DP, Herbison AE (1999) Identification and characterization of estrogen receptor alpha-containing neurons projecting to the vicinity of the gonadotropin-releasing hormone perikarya in the rostral preoptic area of the rat. J Comp Neurol 411:346-358. CrossRef

Sofroniew MV, Weindl A (1978) Projections from the parvocellular vasopressin- and neurophysin-containing neurons of the suprachiasmatic nucleus. Am J Anat 153:391-429. CrossRef Medline

Spergel DJ, Krüth U, Hanley DF, Sprengel R, Seeburg PH (1999) GABA- and glutamate-activated channels in green fluorescent protein-tagged gonadotropin-releasing hormone neurons in transgenic mice. J Neurosci 19:2037-2050. CrossRef

Stevens EB, Shah BS, Pinnock RD, Lee K (1999) Bombesin receptors inhibit $\mathrm{G}$ protein-coupled inwardly rectifying $\mathrm{K}+$ channels expressed in Xenopus oocytes through a protein kinase C-dependent pathway. Mol Pharmacol 55:1020-1027. CrossRef

van den Pol AN (1986) Gamma-aminobutyrate, gastrin releasing peptide, serotonin, somatostatin, and vasopressin: ultrastructural immunocytochemical localization in presynaptic axons in the suprachiasmatic nucleus. Neuroscience 17:643-659. Medline

Wagner EJ, Rønnekleiv OK, Grandy DK, Kelly MJ (1998) The peptide orphanin FQ inhibits beta-endorphin neurons and neurosecretory cells in the hypothalamic arcuate nucleus by activating an inwardly-rectifying $\mathrm{K}+$ conductance. Neuroendocrinology 67:7382. CrossRef Medline

Whorton MR, MacKinnon R (2013) X-ray structure of the mammalian GIRK2- $\beta \gamma$ G-protein complex. Nature 498:190-197. CrossRef Medline

Wintermantel TM, Campbell RE, Porteous R, Bock D, Gröne HJ, Todman MG, Korach KS, Greiner E, Pérez CA, Schütz G, Herbison AE (2006) Definition of estrogen receptor pathway critical for estrogen positive feedback to gonadotropin-releasing hormone neurons and fertility. Neuron 52:271-280. CrossRef Medline

Wray S, Grant P, Gainer H (1989a) Evidence that cells expressing luteinizing hormone-releasing hormone mRNA in the mouse are derived from progenitor cells in the olfactory placode. Proc Natl Acad Sci U S A 86:8132-8136. CrossRef

Wray S, Nieburgs A, Elkabes S (1989b) Spatiotemporal cell expression of luteinizing hormone-releasing hormone in the prenatal mouse: evidence for an embryonic origin in the olfactory placode. Brain Res Dev Brain Res 46:309-318. CrossRef

Wu Y, Wang HY, Lin CC, Lu HC, Cheng SJ, Chen CC, Yang HW, Min MY (2011) GABAB receptor-mediated tonic inhibition of noradrenergic A7 neurons in the rat. J Neurophysiol 105:2715-2728. CrossRef Medline 
Xu Y, Nedungadi TP, Zhu L, Sobhani N, Irani BG, Davis KE, Zhang X, Zou F, Gent LM, Hahner LD, Khan SA, Elias CF, Elmquist JK, Clegg DJ (2011) Distinct hypothalamic neurons mediate estrogenic effects on energy homeostasis and reproduction. Cell Metab 14:453-465. CrossRef Medline

Yano T, lijima N, Kakihara K, Hinuma S, Tanaka M, Ibata Y (2003) Localization and neuronal response of RFamide related peptides in the rat central nervous system. Brain Res 982:156-167. Medline

Yeo SH, Herbison AE (2014) Estrogen-negative feedback and estrous cyclicity are critically dependent upon estrogen receptor- $\alpha$ expression in the arcuate nucleus of adult female mice. Endocrinology 155:2986-2995. CrossRef Medline

Yow TT, Pera E, Absalom N, Heblinski M, Johnston GA, Hanrahan JR, Chebib M (2011) Naringin directly activates inwardly rectifying potassium channels at an overlapping binding site to tertiapin-Q. Br J Pharmacol 163:1017-1033. CrossRef Medline

Zhang C, Bosch MA, Rønnekleiv OK, Kelly MJ (2009) Gammaaminobutyric acid $B$ receptor mediated inhibition of gonadotropinreleasing hormone neurons is suppressed by kisspeptin-G protein-coupled receptor 54 signaling. Endocrinology 150:23882394. CrossRef Medline 